\title{
Raptor abundance and diversity and red-shouldered hawk (Buteo lineatus) habitat characteristics on reclaimed mountaintop mines in southern West Virginia
}

\author{
Melissa J. Balcerzak \\ West Virginia University
}

Follow this and additional works at: https://researchrepository.wvu.edu/etd

\section{Recommended Citation}

Balcerzak, Melissa J., "Raptor abundance and diversity and red-shouldered hawk ( Buteo lineatus) habitat characteristics on reclaimed mountaintop mines in southern West Virginia" (2001). Graduate Theses, Dissertations, and Problem Reports. 1346.

https://researchrepository.wvu.edu/etd/1346

This Thesis is protected by copyright and/or related rights. It has been brought to you by the The Research Repository @ WVU with permission from the rights-holder(s). You are free to use this Thesis in any way that is permitted by the copyright and related rights legislation that applies to your use. For other uses you must obtain permission from the rights-holder(s) directly, unless additional rights are indicated by a Creative Commons license in the record and/ or on the work itself. This Thesis has been accepted for inclusion in WVU Graduate Theses, Dissertations, and Problem Reports collection by an authorized administrator of The Research Repository @ WVU. For more information, please contact researchrepository@mail.wvu.edu. 
Raptor Abundance and Diversity and Red-shouldered Hawk (Buteo lineatus) Habitat Characteristics on Reclaimed Mountaintop Mines in Southern West Virginia

\author{
Melissa J. Balcerzak \\ Thesis submitted to the \\ College of Agriculture, Forestry, and Consumer Sciences \\ at West Virginia University \\ in partial fulfillment of the requirements \\ for the degree of \\ Master of Science \\ in \\ Wildlife and Fisheries Resources
}

Petra Bohall Wood, Ph. D., Chair

Roger J. Anderson, M. S.

John W. Edwards, Ph. D.

Divison of Forestry

Morgantown, West Virginia

2001

Keywords: Mountaintop removal mining; Raptor populations; Red-shouldered Hawk; Buteo lineatus; Habitat 


\title{
ABSTRACT \\ Raptor Abundance and Diversity and Red-shouldered Hawk (Buteo lineatus) Habitat Characteristics on Reclaimed Mountaintop Mines in Southern West Virginia
}

\begin{abstract}
Melissa J. Balcerzak
Raptor abundance and diversity were compared between 4 treatments (grassland, shrub/pole, fragmented forest, and intact forest) over 3 seasons (migration, summer, and winter) on 3 mountaintop/valley fill mines in southern West Virginia. Habitat characteristics of Redshouldered Hawks (Buteo lineatus) were examined at landscape and microhabitat scales. Fortyeight points were surveyed monthly (Feb. 2000-Jan. 2001) using broadcast calls. I quantified microhabitat characteristics within an $11.3 \mathrm{~m}$ radius plot and landscape characteristics within 1000 and $564 \mathrm{~m}$ buffer zones at each point. Abundance was highest in grasslands; richness did not differ among treatments. Overall, I detected a shift from a forest to a grassland raptor community. Red-shouldered Hawks were the most common woodland raptor species occurring almost exclusively in the 2 forest treatments, particularly in the intact forest. Amount of wetland in the landscape was the key characteristic determining presence of Red-shouldered Hawks. Woody debris was positively related to their abundance.
\end{abstract}




\section{Dedicated to the memory of my grandfather,}

\section{Clement Stanley Balcerzak}

Who although leaving this earth before completing my degree, is without a doubt celebrating my accomplishment in heaven. 


\section{ACKNOWLEDGEMENTS}

This project would not have been successful if it were not for the generosity and support of many individuals. Funding was provided by the West Virginia State legislature. Arch Coal, Cannelton, and Amherst Corporations allowed me access to their properties. Ark Land Company provided field housing during the 2000 field season. I particularly thank Ron Vermillion for his assistance with field housing. The West Virginia Cooperative Fish and Wildlife Research Unit, USGS, BRD, provided me with logistical support and equipment for my field work. I would like to thank first and foremost, Petra Bohall Wood, for her assistance and confidence in me throughout my project. I consider myself blessed to have had you as my major advisor and I can only hope that in the future, I can exhibit the same dedication to wildlife research as you do. I would also like to thank my two other committee members, John W. Edwards and Roger J. Anderson, who also supported me in my research and provided me with advice on this manuscript.

I am extremely grateful to the wonderful assistance and support of my fellow raptor researcher and spiritual friend Dorothy Tinkler, who not only provided me with excellent advice and assistance with GIS, but also braved the snow, rain, mud, and numerous other technical difficulties (no heat in the field house!), to help me with my field work. Dorothy, I owe you big time! Besides Dorothy, I should thank Mike Strager for his advice and guidance on analyzing my data with GIS and George Seidel for help with statistical analyses. I would also like to thank my other fellow raptor researcher, Rebecca Smith, for her complete understanding and support in numerous aspects of my project, and for being there with me all the way! Cathy (Katie) Weakland and H. Doug Chamblin, my two fellow mountaintop researchers also provided me 
with companionship and support, working together with me in the field and in front of the computer when combining our research for the Environmental Impact Statement.

I would like to thank the technicians who assisted me with raptor surveys and nestsearching throughout my field season. John D. Anderson IV, was a great help to me during the summer months, spending many hours with me surveying for raptors and searching for Redshouldered Hawk nests. Thanks for always making me laugh and my fieldwork so enjoyable. Todd McCoy and Lisa Kendall also assisted me with my broadcast surveys.

Finally, I would like to thank my family and friends who made all of this possible with their continuous love and encouragement in all my endeavors. First and foremost, I would like to thank my mom and dad for their unconditional love. You have always been there for me and have supported and me in all ways possible: physically, emotionally, mentally, and spiritually. Thank you to my sister Amy and brother Steven, who are the greatest siblings anyone could ever ask for! Amy, you always believed in me, and you were in all ways possible, the best friend I could ever have. I would like to thank all my other friends I met here in West Virginia (in no particular order), who provided me with companionship and spiritual support: Ann Richards, Lisa Puderbaugh, James Gouldman, Cathy Lenter, etc. Lastly, I would like to thank my beloved spiritual amigo Juan Mora, who was always there for me and has brought so much happiness into my life. Mi amor, tú eres una bendición verdadera de Dios y por eso te llevaré dentro de mi corazón para siempre.

\author{
A FINAL PRAYER OF GRATITUDE TO GOD WHO THROUGH UNCONDITIONAL LOVE \\ AND MANY BLESSINGS, IS CONTINUALLY GUIDING ME TO BECOME THE PERSON \\ HE WANTS ME TO BE.
}




\section{TABLE OF CONTENTS}

Abstract...m.t. Page

\section{CHAPTER 1: INTRODUCTION AND LITERATURE REVIEW OF RAPTOR POPULATIONS IN A RECLAIMED MINE LANDSCAPE .................. 1}

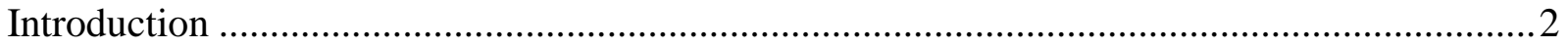

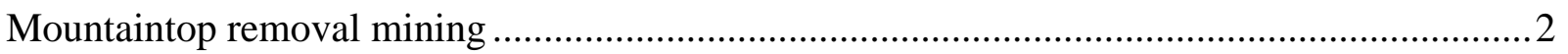

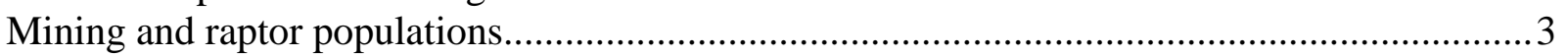

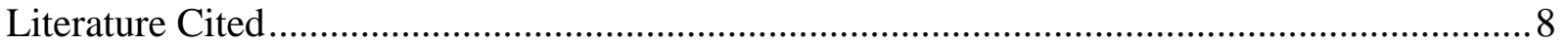

ABUNDANCE AND DIVERSITY OF RAPTORS IN A RECLAIMED MINE LANDSCAPE IN SOUTHERN WEST

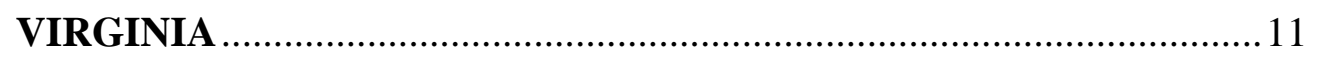

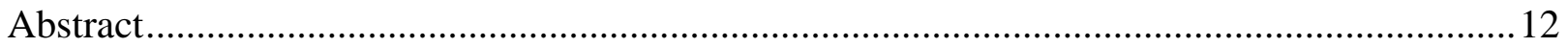

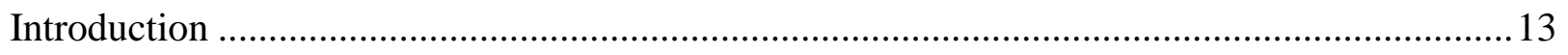

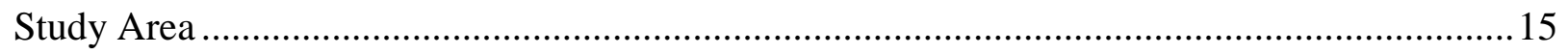

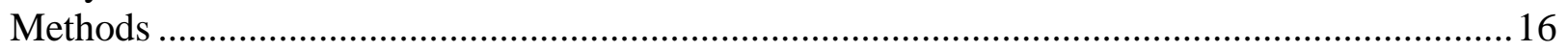

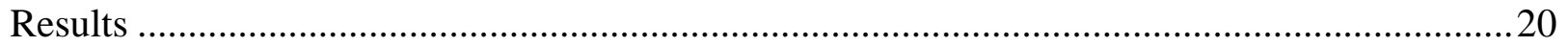

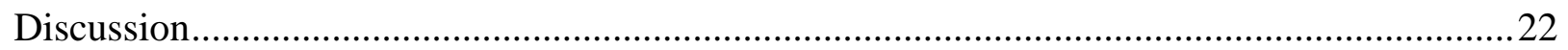

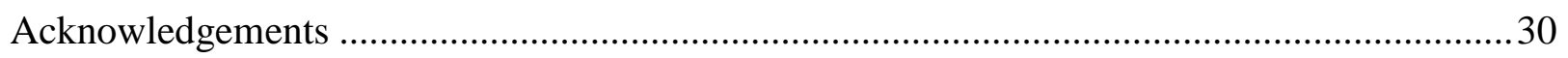

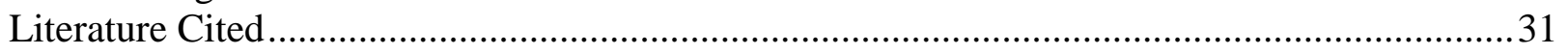

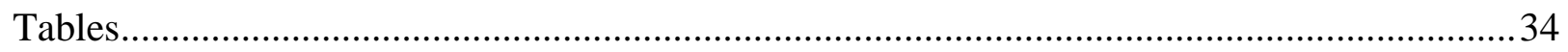

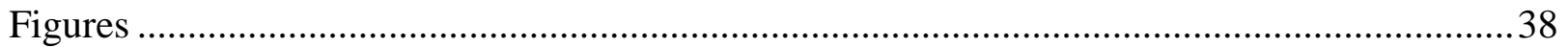

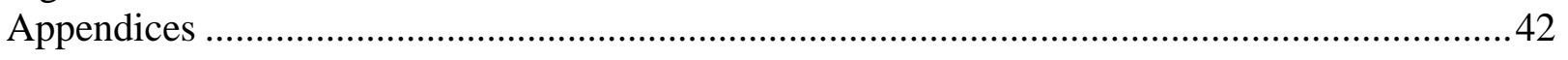

CHAPTER 3: HABITAT CHARACTERISTICS OF RED-SHOULDERED

HAWKS (BUTEO LINEATUS) IN A RECLAIMED MINE

LANDSCAPE AT MICROHABITAT AND LANDSCAPE

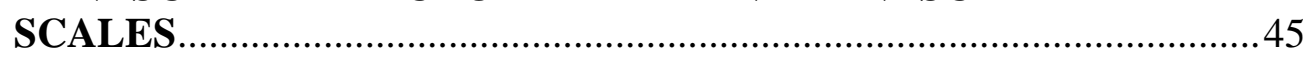

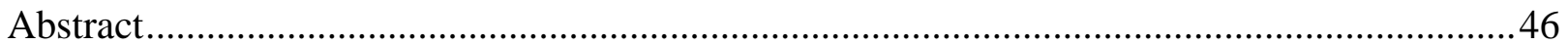

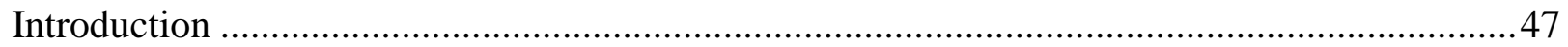

Study Area 


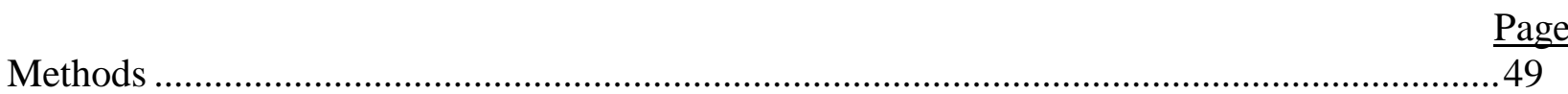

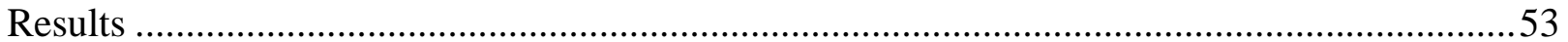

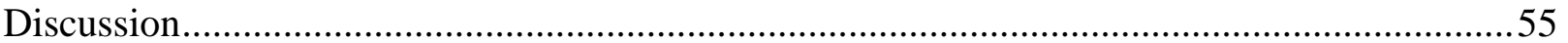

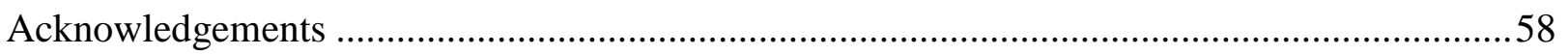

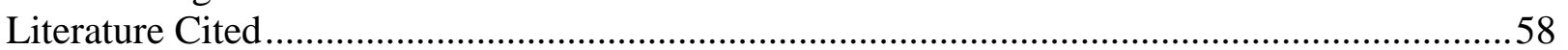

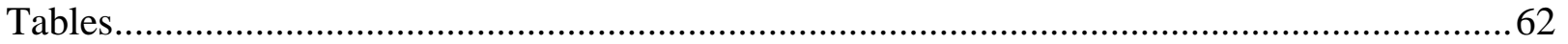

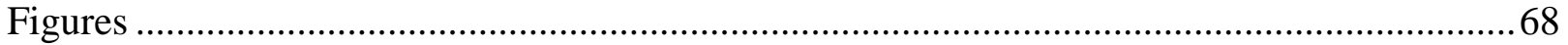

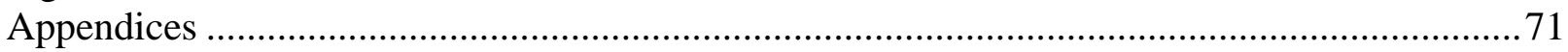

VITA 


\section{LIST OF TABLES}

\section{CHAPTER 2: Abundance and Diversity of Raptors in a Reclaimed Mine Landscape in Southern West Virginia}

Table 2.1. Number of raptor broadcast surveys across treatments within stream

drainages across three mine sites in southern West Virginia, Feburary 2000-

January 2001

Table 2.2. Mean abundance and standard error (SE) for raptor species observed on broadcast surveys across 4 treatments during February 2000-January 2001 in southern West Virginia. Within a row, treatments with the same letter do not differ at $\alpha=0.10$ with Waller-Duncan K-ratio $t$-tests

Table 2.3. Abundance and richness of raptor species observed on roadside surveys for 3 treatment types during July and December 2000 on mines in southern West Virginia.

Table 2.4. Seasonal observations of raptor species ( $w=$ winter, $s=$ summer, $\mathrm{m}=$ migration) on the three mines in each of the four treatments (GR=Grassland, $\mathrm{SH}=$ Shrub/pole, $\mathrm{FR}=$ Fragmented forest, $\mathrm{IN}=$ Intact forest), compared to species expected to occur based on habitat requirements and West Virginia Breeding Bird Atlas (WVBBA) records.

\section{CHAPTER 3: Habitat Characteristics of Red-shouldered Hawks (Buteo lineatus) in a Reclaimed Mine Landscape at Microhabitat and Landscape Scales}

Table 3.1. Abbreviations and descriptions of 19 variables used in landscape analyses of habitat use of Red-shouldered Hawks in southern West Virginia during February 2000-January 2001

Table 3.2. Abbreviations and descriptions of 21 variables used in microhabitat analyses of habitat use of Red-shouldered Hawks in southern West Virginia during February 2000-January 2001

Table 3.3. Significant habitat variables from stepwise logistic regression for Red-shouldered Hawks at landscape (1000 m and $564 \mathrm{~m}$ buffer zones) and microhabitat scales in southern West Virginia during February 2000-January 2001

Table 3.4. Significant habitat variables from stepwise multiple linear regression for Red-shouldered Hawks at landscape (1000 m and $564 \mathrm{~m}$ buffer zones) and microhabitat scales in southern West Virginia during February 2000-January 2001 65 
Table 3.5. Mean and standard error of the 19 landscape variables at both $1000 \mathrm{~m}$ and $564 \mathrm{~m}$ buffer zones for presence/absence of Red-shouldered Hawks at 48 broadcast survey points in southern West Virginia during February 2000-January 2001

Table 3.6. Mean and standard error of the 21 microhabitat variables for presence/absence of Red-shouldered Hawks at broadcast survey points in southern West Virginia during February 2000-January 2001 


\section{LIST OF FIGURES}

\section{CHAPTER 2: Abundance and Diversity of Raptors in a Reclaimed Mine Landscape in Southern West Virginia}

Figure 2.1. Location of mountaintop removal mine sites in southern West Virginia,

February 2000-January 2001.

$\underline{\text { Page }}$

Figure 2.2. Mean abundance, richness, evenness, and Shannon's diversity index for raptors detected during broadcast surveys across 4 treatments in southern WV,

February 2000-January 2001. Treatments with the same letter do not differ at $\alpha=0.1$

Figure 2.3. Mean abundance of open-area raptor species (American Kestrel,

Peregrine Falcon, Northern Harrier, and Red-tailed Hawk) and forest raptor species (Cooper's Hawk, Accipiter spp., Red-shouldered Hawk, Eastern Screech Owl, and Barred Owl) detected on broadcast surveys across 4 treatments in southern West Virginia, February 2000-January 2001. Treatments with the same letter do not differ at the $\alpha=0.1$.

Figure 2.4. Relationship of Red-tailed Hawk abundance and distance to grassland/shrub edge for points within the fragmented and intact forest treatments (A), and relationship of Red-tailed Hawk abundance and distance to forest edge for points within the grassland treatment $(\mathrm{B})$

\section{CHAPTER 3: Habitat Characteristics of Red-shouldered Hawks (Buteo lineatus) in a Reclaimed Mine Landscape at Microhabitat and Landscape Scales}

Figure 3.1. View of $1000 \mathrm{~m}$ and $564 \mathrm{~m}$ buffer zones with digitized landcover for points representing the grassland (top) and shrub/pole (bottom) treatments in southern West Virginia during February 2000-January 2001

Figure 3.2. View of $1000 \mathrm{~m}$ and $564 \mathrm{~m}$ buffer zones with digitized landcover for points representing the fragmented forest (top) and intact forest (bottom) treatments in southern West Virginia during February 2000-January 2001

Figure 3.3. Logistic regression showing quasi-complete separation of data points for the relationship between presence and absence of Red-shouldered Hawks (RSHA) and the variable WETLAND in the fragmented and intact forest treatments 


\section{LIST OF APPENDICES}

\section{CHAPTER 2: Abundance and Diversity of Raptors in a Reclaimed Mine Landscape in Southern West Virginia}

Appendix Table 2.1. Mean decibel level readings taken before and after leaf-out in each

$\underline{\text { Page }}$

of the four treatments in southern West Virginia at distances of 1, 30, and 50-m from

speakerphone.

Appendix Table 2.2. Seasonal mean abundance and species richness of raptors during broadcast surveys across the four treatments in southern West Virginia,

February 2000-January 2001

\section{CHAPTER 3: Habitat Characteristics of Red-shouldered Hawks (Buteo lineatus) in a Reclaimed Mine Landscape at Microhabitat and Landscape Scales}

Appendix Figure 3.1. Relationship between abundance of Red-shouldered Hawks (LOG tranformed) and the variable WOOD (woody debris) with 36 points from the shrub/pole, fragmented forest, and intact forest. Numbers in parenthesis show how many data points overlap

Appendix Figure 3.2. Relationship between abundance of Red-shouldered Hawks (LOG tranformed) and the variable DISTEDGE (distance to nearest microhabitat edge) for multiple linear regression model with points from the fragmented forest and intact forest treatments only. 


\section{PREFACE}

This thesis has been written in the form of 3 chapters. The first chapter is an overall introduction concerning raptor populations and mountaintop removal mining in southern West Virginia using the format for the Journal of Wildlife Management. The second chapter covers abundance and diversity of raptors in a reclaimed mine landscape. Chapter two is formatted for and will be submitted to the Journal of Field Ornithology. The third and final chapter focuses specifically on habitat characteristics of Red-shouldered Hawks (Buteo lineatus) in and around reclaimed mountaintop removal mines at microhabitat and landscape scales. Chapter three is formatted in the appropriate style to be submitted to the Journal of Raptor Research. 


\section{CHAPTER 1:}

INTRODUCTION AND LITERATURE REVIEW OF RAPTOR POPULATIONS IN A RECLAIMED MINE LANDSCAPE 


\section{INTRODUCTION}

Fragmentation of forest habitat on a landscape level has become a major issue in wildlife conservation due to the negative effects on a number of wildlife species (Hunter 1996, Meffe and Carroll 1997). A controversial type of mining in West Virginia called mountaintop removal mining has raised questions concerning the impact that clearing large tracts of land may have on wildlife populations, and in particular raptor populations. Several raptor species, including the Red-shouldered Hawk (Buteo lineatus) are considered primarily forest species and breed in contiguous, mature forest (Hall 1983, Buckelew and Hall 1994). Clearing of forests and creation of fragmented forest patches surrounded by reclaimed grassland may decrease the suitability of mountaintop mined areas and lead to lower abundance of forest raptor populations that occupy and breed in large blocks of intact forest.

\section{MOUNTAINTOP REMOVAL MINING}

Mountaintop removal mining has been used in West Virginia as a large-scale technique for mining coal. Prior mining techniques in West Virginia were either underground mining or “deep mining," or small-scale strip mining, but in 1967, Cannelton Coal Co. in Montgomery, WV started the first mountaintop removal mine (Hansbarger 1999). The mountaintop removal method of mining allowed for the cheap and efficient extraction of coal resources that were once considered largely inaccessible. Initially this technique was used infrequently and on a small scale, but later mountaintop removal mining in West Virginia became more common and sites ranging from 1,819-2,431 ha (4,495-6,007 acres) have been mined and reclaimed. 
Since its initiation in West Virginia, this type of mining has become very controversial due to the large scale of disturbance, the creation of "valley fills," and the consequent impacts to the environment, in particular aquatic watersheds. During the mining process, large portions of a mountaintop are cleared of vegetation and then removed to expose deep underlying coal seams. Once coal is removed, the remaining site is left flattened, the overburden or excess rock/spoil is deposited in nearby valleys, covering the headwaters to valley streams (valley fills), and the site is then reclaimed. The Surface Mining Control and Reclamation Act (SMCRA), Public Law 9587 was passed by the US Congress in 1977 and imposed national regulations on coal mining and reclamation of coal-mined lands. The law required that reclaimed mine land be returned to an "original contour." Although some past mine sites have been restored to an approximation of the original contour, other sites in West Virginia have been left flattened for the purpose of future economic development after mining has concluded (Hansbarger 1999). Due to the overall environmental concerns with this type of mining and especially the filling in of intermittent and perennial streams, the practice has come under much scrutiny over the past several years. A formal Environmental Assessment (EA) is currently being conducted on the impacts of mountaintop removal/valley fill mining in West Virginia. This manuscript is part of a project on terrestrial vertebrate (breeding songbird, raptor, small mammal, and herpetofaunal) populations of forested and reclaimed mine sites for the EA.

\section{MINING AND RAPTOR POPULATIONS}

Past studies concerning the effects of mining on raptor populations have involved smaller scale surface/contour mining, rather than mountaintop removal. These studies described habitat and perch use by raptors, focusing on Red-tailed Hawks, American Kestrels (Falco sparverius), 
and Northern Harriers (Circus cyaneus) in and around reclaimed surface mines (Mindell 1978, Forren 1981, Rohrbaugh and Yahner 1996, Yahner and Rohrbaugh 1998).

Mindell (1978) described habitat use of Red-tailed Hawks (Buteo jamicensis) on 12 reclaimed surface mines ranging from $0.7-40$ ha in northern West Virginia and southern Pennsylvania. He found that red-tails selected natural or strip-mined edge as well as intact deciduous woods, over natural or strip-mined open areas. Higher use of forest edge in proportion to its availability suggested that edge is important to Red-tailed Hawks. He suggested that this was likely due to high prey density along both strip-mined and natural edge, greater number of perches for hunting and resting, and a greater amount of concealment cover along edges.

Deciduous forest also was used more than open areas, although small mammal trapping revealed lower prey densities within the forest. He attributed the selection for deciduous forest over open areas to greater availability of resting, concealment, and nesting areas. He also suggested that open areas were used least, because a majority of the area was out of visual range of the edge and had little value to Red-tailed Hawks due to lack of hunting perches. Although strip-mined habitat was used least, immature Red-tailed Hawks were seen using these areas, possibly because of the presence of high insect populations.

Forren (1981) conducted a later study on 4 reclaimed surface mines in northern West Virginia, the largest mine being 27 ha in size. Artificial perches for raptors were constructed in reclaimed surface mines to determine if this would increase use by raptors. Use of areas with perches did increase compared to those without, but perch use was restricted to a small number of raptor species. Artificial perches were mainly used by American Kestrels (99\%), and minimally by Red-tailed Hawks (0.05\%) and Great-horned Owls (Bubo virginianus) (0.03\%). Perch use peaked in morning and evening, was highest in July and August, and 6-m perches were used 
more than 3-m perches. According to Forren (1981), Red-tailed Hawk and Great-horned Owl use was thought to be minor due to low detectability of small mammals in the thick vegetation found on the surface mine. American Kestrels were able to avoid this problem by preying mostly on insects, which occurred at higher densities than small mammals. Insects and small mammal abundance was measured through sweep netting and trap and removal methods, respectively. Finally, examination of raptor pellets (primarily American Kestrels) showed mostly mammalian remains during May and June, but mostly insect remains during July to October, the period of greatest perch use. Although some raptor species such as Red-tailed Hawks have shown a positive response to forest edge created by a small amount of surface mining, a larger area affected by mining may dissuade use by larger raptors because there is proportionally less edge available, more open area lacking perches, and such areas are likely to be reclaimed with dense vegetation having low prey detectability (Mindell 1978, Forren 1981).

Yahner and Rohrbaugh (1998) compared abundance of diurnal raptors on reclaimed surface mines and agricultural habitats in both northwestern and north-central Pennsylvania. The majority of sightings included 3 species: Red-tailed Hawks, American Kestrels, and Northern Harriers. Other species observed were Cooper's Hawk (Accipiter cooperii), Osprey (Pandion haliaetus), Broad-winged Hawk (Buteo platypterus), Red-shouldered Hawk, Sharp-shinned Hawk (Accipiter striatus), and Northern Goshawk (Accipiter gentilis). Red-tailed Hawks were commonly observed in both habitats in northwestern Pennsylvania and on agricultural habitats in north-central Pennsylvania, but less than expected on reclaimed mines in north-central Pennsylvania. American Kestrels and Northern Harriers both occurred more than expected on reclaimed surface mines in the northwest, but American Kestrels occurred less than expected in agricultural habitats in the north-central region, whereas Northern Harriers occurred less than 
expected in agricultural habitats in the northwestern region. Yahner and Rohrbaugh (1998) concluded that reclaimed surface mines in the northwestern region of Pennsylvania provided suitable habitat for these 3 species, possibly by providing more breeding habitat.

Another study by Rohrbaugh and Yahner (1996) correlated the number of probable and confirmed breeding attempts of Northern Harriers based on Pennsylvania Breeding Bird Atlas data in 6 regions of Pennsylvania with the number of reclaimed surface mines in the same 6 regions. They found that the number of breeding attempts by Northern Harriers in the Pittsburgh Plateau Section of the Appalachian Plateau Province were significantly greater than expected, containing $49 \%$ of all breeding attempts. This region also had a greater number of surface mines than expected, with $75 \%$ of the surface mines. They concluded that Northern Harriers were associated more than expected with the open grassland habitat created after surface mine reclamation, and suggested that harriers may prefer these areas for nesting over agricultural habitats due to less disturbance associated with reclaimed mine sites (Rohrbaugh and Yahner 1996). However they did not actually locate and monitor Northern Harrier nests on reclaimed mines, so their conclusion is speculative.

Mountaintop removal mining may have variable effects on abundance and diversity of raptors, due to the fragmentation of forest and creation of edge and large open grasslands. Temporal variation in raptor use also can affect overall abundance and diversity of raptors throughout the year in mountaintop removal mine habitat. A number of studies conducted on nest site selection of Red-shouldered Hawks have concluded that they select large, even-aged, mature deciduous stands that have a well developed canopy layer, reduced understory, and are in close proximity to water (Portnoy and Dodge 1979, Titus and Mosher 1981, Bednarz and Dinsmore 1981, 1982, Morris and Lemon 1983, Bloom et al. 1993, McLeod 1996, Moorman and 
Chapman 1996, Belleman 1998). During migration and winter seasons, Red-shouldered Hawks still use woodlands, but frequent open habitat much more than during the summer months (Crocoll 1994, Peterson and Crocoll 1992). Similarly to Red-shouldered Hawks, Broad-winged Hawks also nest primarily in continuous deciduous or mixed-deciduous forest in proximity to water, but often use forests with more scattered openings (Titus and Mosher 1981, Crocoll and Parker 1989). In migration Broad-winged Hawks have been observed in forested areas, while during winter they use a variety of forest types as well as forest edges and partly open terrain (Goodrich et al. 1996). Sharp-shinned Hawks typically nest in dense forest stands, often containing some coniferous trees (Buckelew and Hall 1994). In migration and winter, SharpShinned hawks have been reported to use a variety of habitat types with at least some trees or shrubs, and also have been seen in transitional habitats and in open areas (Bohall and Collopy 1984, Bildstein and Meyer 2000). Finally, Barred Owls (Strix varia) most often occur in continuous, mature deciduous forest during the winter, summer, and migration seasons (Buckelew and Hall 1994).

Of those raptor species more tolerant of forest fragmentation, the Red-tailed Hawk is a primary example. Many studies have found that Red-tailed Hawks nest in forested areas in close proximity to habitat edges, with taller trees and more agricultural area associated with nesting macrohabitat (Titus and Mosher 1981, Moorman and Chapman 1996). Mindell (1978) found that Red-tailed Hawks on strip mines showed high use of forest edge in proportion to its availability suggesting that edge was important. Red-tailed Hawks have also been observed in open habitats significantly more than expected on the basis of habitat availability (Bohall and Collopy 1984). Turkey Vultures (Cathartes aura) have generally been observed in transitional habitats, particularly soaring over open areas when foraging (Hall 1983, Buckelew and Hall 1994). 
Cooper's Hawks have been reported to nest in deciduous, mixed, and coniferous forests, with large overstory trees, a mature understory, and edge habitat within the home range of breeding birds (Titus and Mosher 1981, Rosenfield and Bielefeldt 1993). Habitat use during winter and migration seasons is not well described, but one study did show over-wintering Cooper's Hawks in Texas to use agricultural fields (Rosenfield and Bielefeldt 1993). Eastern Screech Owls (Otus asio) have been reported most commonly in both wooded areas and suburban areas (Hall 1983, Buckelew and Hall 1994).

Northern Harriers and American Kestrels commonly occur in open areas. Northern Harriers typically nest in agricultural fields, natural grasslands, and wetland areas throughout their range (Johnsguard 1990). During migration and winter seasons, Northern Harriers are primarily seen in open fields and pastures (Bohall and Collopy 1984). American Kestrels also commonly nest and hunt in agricultural areas. Rohrbaugh and Yahner (1997), found that American Kestrels repeatedly used nest boxes that were located in open habitat, over nest boxes located in semi-open or dense habitat. Reclaimed surface mine areas could be used by both Northern Harriers and American Kestrels, by providing nesting habitat for Northern Harriers and hunting areas for American Kestrels (Forren 1981, Rohrbaugh and Yahner 1996).

\section{LITERATURE CITED}

BEDNARZ, J. C., and J. J. DINSMORE. 1981. Status, habitat use, and management of Redshouldered Hawks in Iowa. J. Wildl. Manage. 45: 236-241.

J. C., and J. J. DINSMORE. 1982. Nest-sites and habitat of Red-shouldered and Red-tailed Hawks in Iowa. Wilson Bull. 94: 31-45.

BELLEMAN, B. A. 1998. Red-shouldered Hawk breeding ecology and habitat use in central Minnesota. M. S. Thesis, University of Minnesota, St. Paul. 71 pp. 
BILDSTEIN, K. L., and K. MEYER. 2000. Sharp-shinned Hawk (Accipiter striatus). In The Birds of North America, No. 482 (A. Poole and F. Gill, eds.). The Birds of North America, Inc., Philadelphia, PA.

BLOOM, P. H., M. D. MCCRARY, and M. J. GIBSON. 1993. Red-shouldered Hawks homerange and habitat use in southern California. J. Wildl. Manage. 57: 258-265.

BOHALL, P. G., and M. W. COLLOPY. 1984. Seasonal abundance, habitat use, and perch sites of four raptor species in north-central Florida. J. Field Ornithol. 55: 181-189.

BUCKELEW, A.R. and G.A. HALL. 1994. Red-shouldered Hawk Buteo lineatus. WV Breeding Bird Atlas, University of Pittsburgh Press, Pittsburgh, 215 pp.

CROCOLL, S. T. 1994. Red-shouldered Hawk (Buteo lineatus). In The Birds of North America, No. 107 (A. Poole and F. Gill, Eds.). Philadelphia: The Academy of Natural Sciences; Washington D.C.: The American Ornithologists' Union.

, S. T., and J. W. PARKER. 1989. The breeding biology of Broad-winged and Redshouldered Hawks in western New York. J. Raptor Res. 23: 125-139.

FORREN, J. D. 1981. Artificial perch use by raptors on reclaimed surface mines in West Virginia. M. S. Thesis, West Virginia University, Morgantown. 199 pp.

HALL, G. A. 1983. West Virginia Birds: distribution and ecology. Spec. Publ. Carnegie Mus. Nat. Hist. No. 7, Pittsburgh. 180 pp.

HANSBARGER, J. L. 1999. Mountaintop removal mining: An Environmental Impact Assessment (EIA) scoping exercise and impact assessment of mining activities on aquatic resources. M. A. Thesis, West Virginia University, Morgantown. 76 pp.

HUNTER, M. JR. 1996. Fundamentals of Conservation Biology. Blackwell Science, Inc., USA.

JOHNSGARD, P. A. 1990. Hawks, Eagles, and Falcons. Smithsonian Institution, USA.

MCLEOD, M. A. 1996. Red-shouldered Hawk habitat use and response to call-playback surveys in North-central Minnesota. M. S. Thesis, University of Minnesota, St. Paul. 77 pp.

MEFFE, G. K, and C. R. CARROLL. 1997. Principles of Conservation Biology, $2^{\text {nd }}$ edition, Sinauer Associates Inc. Publishers, Sunderland, Massachusetts. 729 pp.

MINDELL, D. P. 1978. Habitat use by Red-tailed Hawks in surface mined areas. M. S. Thesis, West Virginia University, Morgantown. 98 pp.

MOORMAN, C. E. and B. R. CHAPMAN. 1996. Nest-site selection of Red-shouldered and Redtailed Hawks in a managed forest. Wilson Bull. 108(2): 357-368. 
MORRIS, M. M. J., and R. E. LEMON. 1983. Characteristics of vegetation and topography near Red-shouldered Hawk nests in southwestern Quebec. J. Wildl. Manage. 47: 138-145.

PETERSON, J. M. C., and S. T. CROCOLL. 1992. Red-shouldered Hawk, Buteo lineatus. Pages 333-351 in K. J. Schneider and D. M. Pence, eds. Migratory nongame birds of management concern in the Northeast. U.S. Dep. Inter., Fish and Wildl. Serv., Newton Corner, Massachusetts. 400 pp.

PORTNOY, J. W., and W. E. DODGE. 1979. Red-shouldered Hawk nesting ecology and behavior. Wilson Bull. 91: 104-117.

ROHRBAUGH, R. W., Jr. and R. H. YAHNER. 1996. Reclaimed surface mines: an important nesting habitat for Northern Harriers in Pennsylvania. Pp. 307-314 in D. M. Bird, D. E. Varland, and J. J. Negro (eds.), Raptors in human landscapes. Academic Press, London, U. K.

, R. W., Jr. and R. H. Yahner. 1997. Effects of macrohabitat and microhabitat on nest-box use and nesting success of American Kestrels. Wilson Bull. 109(3): 410:423.

ROSENFIELD, R. N., and J. BIELEFELDT. 1993. Cooper's Hawk (Accipiter cooperii). In The Birds of North America, No. 75 (A. Poole and F. Gill, Eds.). Philadelphia: The Academy of Natural Sciences; Washington, D. C.: The American Ornithologists' Union.

TITUS, K., and J. A. MOSHER. 1981. Nest-site habitat selected by woodland hawks in the central Appalachians. Auk 98: 270-281.

YAHNER, R. H. and R. W. ROHRBAUGH, Jr. 1996. Grassland birds associated with harrier habitat on reclaimed surface mines. Northeast Wildl. 53: 11-18.

, R. H. and R. W. ROHRBAUGH, Jr. 1998. A comparison of raptor use of reclaimed surface mines and agricultural habitats in Pennsylvania. J. Raptor Res. 32(2): 178-180. 


\section{CHAPTER 2:}

\section{ABUNDANCE AND DIVERSITY OF RAPTORS IN A RECLAIMED MINE}

LANDSCAPE IN SOUTHERN WEST VIRGINIA 


\section{ABSTRACT}

Fragmentation and conversion of forests to open expanses of grassland by mountaintop removal mining may have variable effects on many raptor species. The purpose of this study was to compare the abundance and diversity of raptors in an unmined landscape (intact forest treatment) with that of a reclaimed landscape (grassland, shrub/pole, fragmented forest treatments) during three seasons (migration, summer, and winter) to determine the effect of mountaintop removal mining on the raptor community. Study areas included three mountaintop removal mines: Hobet 21 mine in Boone County, WV (2,431 ha), Daltex mine in Logan County, WV (1,925 ha), and Cannelton mine on the border of Kanawha and Fayette County, WV (2,180 ha). Raptor abundance and diversity were measured during broadcast call surveys at 48 stations, distributed equally among the four treatments during February 2000-January 2001. Mean abundance of raptors was highest in the grassland treatment, while diversity (richness, eveness, and Shannon's diversity index) did not differ among treatments. American Kestrels (Falco sparverius) and Red-shouldered Hawks (Buteo lineatus) showed highest use in areas typical of these species. Northern Harriers (Circus cyaneus) had highest use in the grassland treatment during migration and winter, when they are typically moving south from northern breeding grounds and over-wintering on the mines. Turkey Vultures (Cathartes aura) had highest use in grasslands during summer, when they were often observed soaring in groups high above open areas. Other notable raptor species recorded on the mines were Short-eared Owls (Asio flammeus) and Peregrine Falcons (Falco peregrinus), both of which have potential to breed on reclaimed mine land. Overall, mountaintop removal mining appears to be shifting the species composition of raptors from a predominantly forested community to a grassland community.

Keywords: $\quad$ mountaintop removal mining, raptors, broadcast call surveys 


\section{INTRODUCTION}

Mountaintop/valley fill mining (MTMVF) in West Virginia changes a primarily forested landscape into a landscape that consists of large expanses of grassland, early successional shrub habitat, and fragmented forest patches, which may have variable effects on the raptor community. Several raptor species in West Virginia, including the Red-shouldered Hawk (Buteo lineatus) are considered primarily forest species and breed in contiguous, mature forest (Hall 1983, Buckelew and Hall 1994). Clearing of forests and creation of fragmented forest patches surrounded by reclaimed grassland may decrease the suitability of mountaintop mined areas and lead to lower abundance of forest raptor populations that occupy and breed in large blocks of intact forest.

Few studies have examined the effects of mining on raptor populations, and all involved smaller-scale surface/contour mining (tens of ha), rather than mountaintop mining (hundreds of ha). Red-tailed Hawks selected natural or strip-mined edge in greater proportion to its availability on 12 reclaimed surface mines in northern West Virginia and southern Pennsylvania (Mindell 1978). On reclaimed surface mines in northern West Virginia, Forren (1981) found that artificial perches increased use of an area by raptors. Perch use was restricted to a small number of raptor species, mostly American Kestrels with a few Red-tailed Hawks and Great-horned Owls (Bubo virginianus). Yahner and Rohrbaugh (1998) compared abundance of diurnal raptors on reclaimed surface mines and agricultural habitats in both northwestern and north-central Pennsylvania, observing mostly Red-tailed Hawks, American Kestrels, and Northern Harriers. American Kestrels and Northern Harriers both occurred more than expected on reclaimed surface mines in the northwest, and they concluded that reclaimed surface mines in the northwestern region of Pennsylvania provided suitable habitat for these species. 
The conversion of forest tracts to earlier successional habitats will likely change the raptor community in an area from predominantly forest-dependent species to open-country species. Red-shouldered Hawks select large, even-aged, mature deciduous stands that have a well developed canopy layer, reduced understory, and are in close proximity to water (Portnoy and Dodge 1979, Titus and Mosher 1981, Bednarz and Dinsmore 1981, 1982, Morris and Lemon 1983, Belleman 1998). The slow succession of reclaimed mountaintop mines to mature forest, may keep Red-shouldered Hawk abundance low on mined land for many years. Other species such as the Red-tailed Hawk (Buteo jamiacensis), being more tolerant of forest fragmentation and open areas, may increase in abundance (Bednarz and Dinsmore 1982, Preston and Beane 1993). Meanwhile, Northern Harriers (Circus cyaneus) and American Kestrels (Falco sparverius), species typically found in wetlands or agricultural areas, may also increase in abundance due to the newly created grassland habitat after mining has concluded (Yahner and Rohrbaugh 1998).

To determine the impact that large-scale mountaintop removal mines are having on raptor populations, the major objective of this study was to quantify raptor abundance, diversity, and species-specific abundance on three mountaintop removal mine sites within four treatments: intact forest, fragmented forest, young reclaimed mine (grassland), and older reclaimed mine (shrub/pole). The intact forest treatment represents the pre-mined landscape, while the fragmented forest, young reclaimed mine, and older reclaimed mine treatments represent the post-mined landscape. The study was conducted throughout the year to include seasonal variability of raptor populations in these areas. 


\section{STUDY AREA}

Study areas were associated with three mountaintop removal mines located in southern West Virginia (Fig. 2.1). The largest site at approximately 2,431 ha was Hobet 21 mine located in the Mud River drainage basin in Boone County. The Daltex mine, located in the Spruce Fork drainage basin in Logan County, was smallest at approximately 1,819 ha. The Cannelton mine, approximately 2,180 ha in size, was located in the Twentymile Creek drainage basin along the border of Kanawha and Fayette Counties. Study areas were divided into four treatments: intact forest, fragmented forest, young reclaimed mine (grassland), and older reclaimed mine (shrub/pole). Intact forest study areas were undisturbed by mining activities and were located within the same river drainage basin as the mine site. Fragmented forest was a tract of forest almost entirely surrounded by reclaimed mine land. Young reclaimed mine areas consisted of mostly grasses and some scattered shrubs, and were estimated to be 5-19 years of age. Older reclaimed mine areas contained shrub and pole-sized vegetation and ranged from 13-27 years of age.

The intact and fragmented forest areas were comprised of mature Appalachian hardwood species typical of mixed mesophytic forest (Strausbaugh and Core 1977). Common species included red and white oak (Quercus rubra and Quercus alba), pignut and shagbark hickory (Carya glabra and Carya ovata), yellow-poplar (Liriodendron tulipifera), and American beech (Fagus grandifolia). Primary vegetation on young reclaimed mine (grassland) areas included tall fescue (Festuca arundinacea), sericea (Lespedesa cuneata), and autumn olive (Elaeagnus umbellata), but also included multiflora rose (Rosa multiflora), legumes such as birdsfoot Trefoil (Lotus corniculatus) and purple vetch (Vicia americana), and occasionally patches of planted wheat (Triticum aestiuum L.). There were two distinct older reclaimed mine (shrub/pole) 
treatments. The first type consisted mostly of black locust (Robinia pseudoacacia), European black alder (Alnus glutinosa), and Rubus species. The second type mostly consisted of coniferous species such as red pine (Pinus resinosa), scotch pine (Pinus sylvestris), and pitch pine (Pinus rigida).

\section{METHODS}

Raptor abundance and habitat use were quantified at 48 sampling points located approximately $350-1,320 \mathrm{~m}$ apart $($ mean $=732.8)$ and divided equally among the four treatments (Table 2.1). Points were selected from a number of stream drainages representing each treatment type, to coincide with a concurrent water quality study conducted by the Environmental Protection Agency. Points were sampled monthly (February 2000-January 2001) in each of the four treatments with approximately equal numbers of sample points over the 3 mines. All 48 points were sampled over a 4-6 day period. Points from at least 3 treatments were sampled on a given day to minimize temporal variability between treatments. The order that points were sampled on a given day was randomly established during the first survey. On subsequent surveys, the order in which points were sampled was systematically varied by the 3 individual mines and through 3 daily time periods: early, mid and late day.

Broadcast surveys were used to sample raptor populations because broadcasting conspecific vocalizations has been shown to be an effective way to survey targeted raptor species (Rosenfield et al. 1988, Mosher et al. 1990, Kennedy and Stahlecker 1993). During winter months, broadcast surveys were conducted from one-half hour after sunrise until 1600 hrs because raptors can be active throughout the day during cooler weather. During summer months, broadcast surveys were conducted from one-half hour after sunrise until $1300 \mathrm{hrs,} \mathrm{because} \mathrm{shifts}$ 
in raptor activity in the afternoon may reduce the detectability of certain raptor species such as Red-tailed Hawks and Accipiters (Bunn et al. 1995).

Broadcast surveys lasted 10 minutes, consisting of approximately 5 minutes of broadcasting vocalizations and 5 minutes of observation/listening time, and were based on the protocol suggested by Fuller and Mosher (1987). Six calls were broadcast for a 20 second duration at 1 minute intervals ( 20 seconds of vocalization, followed by a 40 second listening period), leaving a final listening period of 4 minutes and 40 seconds and thus making a total of 10 minutes. The equipment used to broadcast calls was a TOA Transistor ${ }^{\circledR}$ megaphone speaker with an attached CD player. The speaker was held $1.5 \mathrm{~m}$ above the ground and rotated $120^{\circ}$ between each broadcast. Broadcast call volume was adjusted between 100-110 $\mathrm{db}$ at $1 \mathrm{~m}$ from the megaphone speaker. Leaves on trees had little effect on call volume when it was measured at 1 , 30, and $50 \mathrm{~m}$ in each treatment type prior to and after leaf-out in spring (Appendix table 2.1).

Both Great-horned Owl (Bubo virginianus) and Red-shouldered Hawk vocalizations were used during the survey period. Both calls were recorded from the Peterson Field Guide to Bird Songs of Eastern and Central North America CD (Peterson Field Guide Series 1990). The 6 vocalizations alternated between Great-horned Owl and Red-shouldered Hawk calls. Mosher and Fuller (1996) reported that Great-horned Owl vocalizations were able to elicit responses from a number of raptor species on a single survey, unlike conspecific vocalizations to which usually only the conspecific responds. McLeod and Andersen (1998) compared conspecific and Greathorned Owl calls in attracting Red-shouldered Hawks, and found that although Red-shouldered Hawks responded to Great-horned Owl vocalizations, response rates were higher for conspecific vocalizations earlier in the season and in the day. Therefore, both calls were used within a survey period to maximize detection of a number of raptor species as well as specifically target Red- 
shouldered Hawks. I randomly selected the Great-horned Owl or Red-shouldered Hawk call to start the first survey each day, with the second survey starting with the call not previously used, and thus alternating throughout the entire survey session each day.

Two observers trained in identification of raptors by sight and sound were present at every survey. I was the primary observer and was present at each survey. The second observer alternated between seven individuals. During the 10-minute survey period, both observers simultaneously watched and listened for raptors. Surveys were not conducted in inclement weather (moderate to heavy rain, fog, or wind).

Data recorded on surveys included weather conditions (cloud cover/precipitation, wind, and temperature), nearest edge type, distance to edge, latency (time from start of survey until first raptor detection), general vegetative cover characteristics (size class of trees, amount of cover, dominant plant species), raptor species detected, age and sex (if possible), behavior during detection (perch and call, flyby and call, silent perch, silent flyby, vocal only), time each individual bird was seen, estimated distance bird was from observer, and treatment in which a bird was first detected. Survey data were summarized as mean number of individuals detected within a treatment or season. The winter season included December-March, the summer season April-July, and the migration season August-November.

Roadside surveys also were conducted at least twice on each of the three mines, once in late July and later in early December. These surveys consisted of driving a specified route at 16 kmph (10 mph) through grassland, shrub/pole, and forest fragment treatments, while looking and listening for raptors. The intact forest treatment was not included in roadside surveys because this treatment had no drivable roads. Each roadside survey period was similar in time and length (approximately $2 \mathrm{hrs}$ for 16-24 km) and covered approximately equal amounts of the three habitat 
treatments for each mine. The only exception was the Daltex mine, which lacked areas representative of the shrub/pole treatment. All raptor species observed were recorded along with the time, distance away from the road (m), habitat, and behavior. Other data recorded were the length of survey $(\mathrm{km})$, start and end time of survey, and weather conditions (cloud cover, precipitation and wind).

Analysis of variance (ANOVA) was used to compare overall mean abundance, richness, evenness, and Shannon's diversity index for raptors among treatments. Mean abundance was calculated as the mean number of detections for a group or individual species across all treatments and seasons. Richness was defined as the number of species detected in all treatments and seasons. Evenness was a measure of distribution and abundance of species across treatments, while Shannon's diversity index was calculated as an overall measure of diversity across treatments, and included both richness and evenness (Magurran 1988). For the ANOVA, mean abundance and richness were dependent variables, while treatment, season, and the interaction between treatment and season were independent variables. Evenness and Shannon's diversity index also were dependent variables, while treatment was the independent variable for analyses. ANOVA also was used to compare abundance of raptors grouped into open-area and forest species across treatment and season, where open-area and forest species abundance were the dependent variables and treatment, season, and the interaction between treatment and season were the independent variables. Lastly, species-specific abundance was compared among treatments and also season if there was a treatment/season interaction. For this analysis, species-specific abundance was the dependent variable and treatment, season, and the treatment/season interaction were the independent variables. When differences between treatments or season were detected by the ANOVA, the Waller-Duncan K-ratio $t$ test was used to determine where those differences 
occurred. Turkey Vultures were excluded from the analysis of overall mean abundance of raptors and mean abundance of open-area species, because vultures do not respond to broadcast surveys as do other raptor species. All statistical analyses were completed using the SAS ${ }^{\circledR}$ GLM procedure (SAS ${ }^{\circledR}$ Institute 1991) with the significance level set at $\alpha=0.10$.

\section{RESULTS}

From February 2000-January 2001, a total of 199 observations of raptors were made on broadcast surveys. The greatest number of sightings were of Turkey Vultures (Cathartes aura) (109 sightings), with Red-tailed Hawks (26), Northern Harriers (21), and Red-shouldered Hawks (18) forming the majority of the remainder. In all, 9 species were observed on broadcast surveys (Table 2.2).

Overall mean abundance of raptors (excluding Turkey Vultures) observed on broadcast surveys was significantly higher in the grassland treatment (Fig. 2.2) than all other treatments $(F$ $=6.48, \mathrm{df}=3, P=0.0003)$. Abundance did not differ among seasons $(F=1.36, \mathrm{df}=2, P=$ $0.2563)$ and there was no interaction between treatment and season $(F=0.95$, $\mathrm{df}=6, P=0.4561)$. Overall mean richness of raptors observed on broadcast surveys did not differ among treatments $(F=0.31, \mathrm{df}=3, P=0.8193)$ or season $(F=0.38, \mathrm{df}=2, P=0.6841)$, with no interaction between treatment and season $(F=1.03, \mathrm{df}=6, P=0.4030)$. Mean evenness of raptors across treatments was not significantly different $(F=2.11, \mathrm{df}=3, P=0.1122)$, along with Shannon's diversity index $(F=0.33$, df $=3, P=0.8048)$. Mean abundance of raptors grouped into openarea species [American Kestrel, Peregrine Falcon (Falco peregrinus), Northern Harrier, and Redtailed Hawk], was significantly higher in the grassland treatment than all other treatments $(F=$ 14.42, $\mathrm{df}=3, P<0.0001$ ) (Fig. 2.3). Mean abundance of open-area species did not differ among 
seasons $(F=0.93$, df $=2, P=0.3953)$, nor was there an interaction between treatment and season $(F=1.11, \mathrm{df}=6, P=0.3556)$. Mean abundance of raptors grouped into forest species [Cooper's Hawk (Accipiter cooperii), Accipiter spp., Red-shouldered Hawk, Eastern Screech Owl (Otus asio), and Barred Owl (Strix varia)] did not significantly differ among treatments $(F=1.63$, df $=$ 3, $P=0.1823)$ or season $(F=1.39, \mathrm{df}=2, P=0.2509)$, with no interaction between treatment and season $(F=1.30, \mathrm{df}=6, P=0.2543)$.

Mean abundance of individual species also was compared across the four treatment types and three seasons. Of the nine species observed on surveys, abundance differed across treatments for American Kestrels and Red-shouldered Hawks. Mean abundance of American Kestrels was significantly highest in the grassland treatment, with no observations in other treatments (Table 2.2). Red-shouldered Hawk mean abundance was significantly higher in the intact forest treatment than the grassland treatment. However, the mean abundance of Red-shouldered Hawks for the intact forest treatment, was not significantly different from the fragmented forest or shrub/pole treatments. Two species (Northern Harrier and Turkey Vulture) had significant interactions between treatment and season, so treatments were compared within each season. Northern Harrier mean abundance was significantly different across treatments during the migration and winter seasons, with greatest abundance in the grassland treatment. For Turkey Vultures, abundance differed across treatments during the summer season with highest abundance in the grassland treatment. Results of Peregrine Falcon, Cooper's Hawk, Accipiter spp., Redtailed Hawk, Eastern Screech Owl, and Barred Owl mean abundance were not significant across treatments or seasons.

During roadside surveys on the three mines, overall abundance and richness was highest in the grassland treatment at the Hobet mine (Table 2.3). Overall, I detected 7 species on 
roadside surveys. Only two species, the Red-tailed Hawk and Turkey Vulture, were observed in all three treatments surveyed.

\section{DISCUSSION}

Overall mean abundance of raptors observed on broadcast surveys differed among the four treatments, being highest in grasslands. Although the raptor with the highest number of observations (Turkey Vulture) was excluded from the analysis, other raptors that are typically observed in open areas had the second and third highest number of observations during broadcast surveys. Abundance may have been highest in the grassland treatment because of a gain in species during both migration and winter (an 8-month period), including predominantly openarea species. Short-eared Owls, Rough-legged Hawks, and in particular Northern Harriers were moving south from their breeding grounds in the north and often over-wintered on the mines. During the same 8-month period, few forest-associated species such as the Broad-winged Hawk, left the study area and migrated further south. During the 4-month summer (breeding) season, study areas maintained some of the open-area species such as the Northern Harrier. Red-tailed Hawks also added to the abundance in the grassland treatment, because they often were observed soaring over grasslands during all seasons. All of the measures of diversity (mean richness, evenness, and Shannon's diversity index) were not significantly different across treatments. This indicates that as the landscape was converted from a primarily forested area to an open, grassy area, the decrease in the number of forest species was supplemented by an increase in open-area species such as the Northern Harrier and American Kestrel.

Mean abundance of open-area species in the grassland treatment was significantly higher than all other treatments, independent of season. Higher mean abundance in the grassland was 
once again most likely due to the large number of Red-tailed Hawks observed during the summer and higher numbers of Northern Harriers during winter and migration. The results of the forest species analysis showed that there was no significant difference among treatments, even though only 2 species (1 observation each) were detected in the grassland treatment. I believe that this is partly due to low sample sizes, but more likely because of the variability in habitat requirements for the species in this group. Several species in the analysis, such as the Eastern Screech Owl (observed equally between the fragmented forest and shrub/pole treatment), are not intact forest specialists. Consequently, it is more important to look at individual species abundance across treatments and season.

The analysis of individual species mean abundance indicates that some species showed higher use of particular treatment types over others. American Kestrels had higher abundance in the grassland treatment than all other treatments, independent of season. This result is not surprising, since American Kestrels are generally found in more open habitat and are rarely seen over forested habitat except possibly during migration (Johnsgard 1990). Turkey Vultures also had the highest abundance in the grassland treatment during summer, although sightings occurred in all treatments. Turkey Vultures primarily forage over large open areas of variable habitat (Bent 1937, Buckelew and Hall 1994), although they require ledges or hollow stumps for nesting (Johnsgard 1990).

Northern Harriers, an open-country species, had the highest abundance in the grasslands during both migration and winter. During migration Northern Harriers are flying south from northern breeding areas and some birds are remaining on the mines during winter months. Northern Harriers were observed in low numbers during the summer in only the grassland and shrub/pole treatments. They have been reported in other open areas in West Virginia such as 
Canaan Valley, but there are no breeding records in the southwestern part of the state (Buckelew and Hall 1994). Historically, Northern Harriers have occurred in low numbers in West Virginia due to lack of open areas (wetlands, agricultural lands) for breeding. Recent observations on grassland and shrub areas indicate that they are using reclaimed mountain top removal mines during the summer months. Although no evidence of breeding was found, it is important to determine whether these areas are capable of supporting a breeding population of Northern Harriers. In Pennsylvania, nests or young of Northern Harriers were often observed in wetland areas within surface mines (Rohrbaugh and Yahner 1996). Creating and maintaining wetland areas within the reclaimed grassland sites would likely enhance potential breeding habitat for Northern Harriers on mountaintop mines in West Virginia.

Red-shouldered Hawks had significantly higher abundance in the intact forest treatment than the grassland treatment, but not compared to the fragmented forest or shrub/pole treatments. Observations of birds outside the treatment at the survey point were dropped from analyses, so 18 of 23 detections ( 9 intact forest, 4 fragmented forest, 4 shrub/pole, 1 grassland) were used in statistical comparisons among treatments. When all 23 detections of Red-shouldered Hawks were classified into the habitat treatment where the bird occurred: 10 were in intact forest, 8 in fragmented forest, 4 in shrub/pole, and 1 in grasslands. Many studies have shown these birds to nest primarily in contiguous, mature forest habitat (Bednarz and Dinsmore 1981, Morris and Lemon 1983, Belleman 1998). During my study, only one Red-shouldered Hawk responded to broadcast surveys in fragmented forest during the breeding season (March-June). Overall, more Red-shouldered Hawks responded in intact forest during the breeding season (4 detections), including one instance where two birds were observed together during a survey and may have been a nesting pair. Additionally, 2-3 Red-shouldered Hawks (possibly juveniles) were observed 
at an intact site in August, so breeding may have occurred in the area. So, it is possible that Redshouldered Hawks may be using fragmented patches of forest for hunting or roosting, but using intact forest for nesting. They were detected in the shrub/pole and grassland treatment only during migration and winter periods (Appendix table 2.2). Some studies have reported greater use of more open areas and woodland edges by Red-shouldered Hawks during the winter months as compared to summer months (Bohall and Collopy 1984, Crocoll 1994).

Red-tailed Hawk abundance was not significantly different across treatment or season; they occurred in every treatment type. Several studies have described the Red-tailed Hawk as an open-country raptor using agricultural fields, pastures, and forest edges more than other woodland raptor species with little fluctuation in habitat use across seasons (Bent 1937, Bednarz and Dinsmore 1982, Preston and Beane 1993, Moorman and Chapman 1996). Thus they are able to better tolerate the effects of forest fragmentation and conversion of forest to open areas. With the exception of one sample point, all Red-tailed Hawks were detected at points located within $300 \mathrm{~m}$ of the reclaimed grassland/forest edge (Fig. 2.4).

During roadside surveys, overall abundance and richness were highest in the grasslands at the Hobet 21 mine. Generally results from roadside surveys were similar to results from the broadcast surveys. Red-tailed Hawks and Turkey Vultures were observed in all 3 treatments during roadside surveys, while American Kestrels, Northern Harriers, and a Peregrine Falcon were observed in open habitats. Two species not observed on broadcast surveys, the Broadwinged Hawk and Rough-legged Hawk, were observed on roadside surveys. Broad-winged Hawks were observed on roadside surveys in fragmented forest and incidentally in intact forest treatments. They are considered mainly forest species that nest in contiguous, mature forest, although they do nest in forests with openings or water nearby (Goodrich et al. 1996). Rough- 
legged Hawks were detected on roadside surveys and as incidental observations in the grasslands during winter at the Hobet mine. Rough-legged Hawks have been observed in West Virginia during migration along mountain ridges and during winter around Charleston in Kanawha County (Hall 1983).

In an overall comparison of raptor species observed on the three mines during broadcast surveys, roadside surveys, and incidental observations to what would be expected in West Virginia from breeding records and habitat requirements, a number of species unexpectedly occurred on the mines (Table 2.4). Short-eared Owls (Asio flammeus) and Peregrine Falcons were observed in the grassland treatment. Other species, such as Broad-winged Hawks, Cooper's Hawks, and Sharp-shinned Hawks were also observed in habitats where they were not expected in West Virginia. Finally, the American Kestrel, Red-tailed Hawk, Barred Owl, Eastern Screech Owl, and Turkey Vulture were all observed in areas mostly consistent with what was expected. Short-eared Owls can occasionally be seen in West Virginia during migration to and from breeding grounds further north or throughout winter months (Hall 1983), but were sighted in increasing numbers on reclaimed mountaintop mine sites during the summer/breeding months. Short-eared Owls were observed frequently by researchers during the summer of 2001 on two mines (Ammer and Weakland, per. comm.), particularly in younger reclaimed grassland areas, which are dominated by patchwork grasses with an underlying gravel surface and occasional shrubs. Short-eared Owls are considered rare or uncommon migrants and winter residents in West Virginia due to lack of open habitat such as fields, marshes, and thickets, which this species uses during the non-breeding season (Hall 1983, Holt and Leasure 1993). Most sightings have occurred in the northern and western counties of West Virginia (Hall 1983). Observations of Short-eared Owls in grasslands during summer, suggests that reclaimed mountaintop mines may 
provide breeding habitat for this species. Short-eared Owls typically breed in expanses of prairie, coastal grasslands, shrub-steppe, and tundra, with nests located in dry areas concealed by minimal vegetation (Holt and Leasure 1993).

Another unexpected raptor species, the Peregrine Falcon was observed on the reclaimed grassland areas of two mountaintop mines. In particular, a pair of Peregrine Falcons was frequently observed during migration and throughout the summer months near a rocky "highwall" left after mining at the Daltex mine, although no evidence of breeding was found. Even prior to 1950 and the widespread use of DDT, Peregrine Falcons were rare in West Virginia, although there were some nesting records from documented eyries in Mineral, Greenbrier, and Morgan counties. More recent breeding attempts in the state were recorded in 1991 and 1992 in Grant County after a release of birds in the New River Gorge in 1987-1989 (Buckelew and Hall 1994), and in 2000-2001 with a pair nesting near North Fork Mountain (C. Stihler, pers. comm.). There are no confirmed breeding records of Peregrine Falcons in Kanawha, Boone, or Logan counties (Buckelew and Hall 1994) and most sightings of Peregrine Falcons in the state have been during migration along mountain ridges (Hall 1983). The highwall at the Daltex mine was used by both Peregrine Falcons for perching and hunting. Nesting habitat for Peregrine Falcons could be provided by focusing current mine reclamation efforts to restoring some of the mountainous cliffs and ledges historically present in West Virginia.

Broad-winged Hawks were observed not only in intact forest as expected in West Virginia, but in forest fragments, shrublands, and grasslands. Broad-winged Hawks are considered mainly a forest species that nests in contiguous mature forest, although they appear to nest in forests with more openings than Red-shouldered Hawks (Titus and Mosher 1981, Crocoll and Parker 1989). The observations of Broad-winged Hawks in grassland areas were of birds 
soaring and may have been instances where the birds were moving from one forested area to another.

Cooper's Hawks and Sharp-shinned Hawks were observed in habitats where they were not expected in West Virginia. Cooper's Hawks were sighted in grassland areas during migration, with observations of Sharp-shinned Hawks both in grassland during summer and shrub during winter, and a sighting of an Accipiter (either Cooper's or Sharp-shinned Hawk) in a forest fragment during winter. Little information is available on Cooper's Hawk habitat use during migration, but it has been noted that this species uses forest edge habitat as primary hunting areas in its home range during breeding and has been seen in agricultural fields while over-wintering in Texas (Rosenfield and Bielefeldt 1993). Similar to Cooper's Hawks, Sharp-shinned Hawks have been observed in more open areas and transitional habitat during the winter months than summer (Bildstein and Meyer 2000). The observation of a Sharp-shinned Hawk in grasslands during summer, may have been a bird passing between forest habitats.

Mountaintop removal/valley fill mining has had an effect on overall raptor abundance and species composition in the raptor community. Woodland species such as the Red-shouldered Hawk and Broad-winged Hawk were rarely observed in the open grassland and shrub treatments, but more commonly observed in intact forest. Open-country species such as Northern Harriers and American Kestrels were most often observed in grasslands, with no observations occurring in wooded areas. These results suggest that mountaintop removal/valley fill mining is providing an overall shift from a woodland raptor community to a grassland raptor community.

Certain measures could be taken to enhance reclaimed mountaintop mines for raptors. Creation and maintenance of wetlands on mines, especially marsh wetlands containing emergent vegetation, may encourage breeding by Northern Harriers. Reclamation that includes rock 
structure similar to the cliffs and ledges historically present in West Virginia could provide potential breeding habitat for Peregrine Falcons. Due to the openness of reclaimed mine sites and a lack of trees, perches for hawks could be beneficial to the grassland raptor community. Many Red-tailed Hawks were observed soaring over the grasslands, possibly because there were few suitable perches for hunting. Also, they often perched on the few trees, poles, and telephone wires available, as did American Kestrels. Forren (1981) found that reclaimed surface mines where artificial perches were constructed showed higher use by raptors (mostly American Kestrels and Red-tailed Hawks) than those without. Nest boxes placed on the existing telephone poles across the mines, could also benefit the current American Kestrel population. Piles of brush associated with perches on reclaimed mines may also benefit raptors by providing habitat for small mammals and thus increase the number of prey available to hunting raptors.

Although the creation of large open expanses of grassland and shrub areas is beneficial to some raptor species, it is detrimental to other raptor species that use primarily forest as breeding and foraging areas. Raptors that are forest specialists will likely continue to be displaced and increasingly unable to use the large open areas and fragmented forest patches that result as current mountaintop/valley fill mines continue to expand. Only one observation of a Redshouldered Hawk occurred in the reclaimed grasslands (a juvenile during winter), while only four detections occurred in shrub/pole. Large expanses of early-successional habitat were generally unsuitable for this species and will not become suitable until areas revert to mature forest. Woodland raptors that are generalists and require a combination of early-successional, mature forest, and edge habitats (e.g. Red-tailed Hawk), will be increasingly unable to use larger patches of reclaimed mine lands without interspersion of some mature forest. Fewer Red-tailed Hawks were observed at grassland points further away from a forest edge. 
Although, this study is limited in that we surveyed only for diurnal raptors and because the survey technique contains some inherent bias in detectability among treatments, it does provide an overall description of raptors using reclaimed mountaintop mine landscapes. All three study sites were large $(1,819-2,431$ ha of reclaimed land), therefore more study is needed to determine how size of reclaimed mines will affect the raptor community, especially forest species. A study specifically incorporating size of reclaimed mines and how they are used by open-area, edge, and forest species would be beneficial. Also, further study on grassland specialist species such as the Northern Harrier and Short-eared Owl is needed to confirm whether these species are breeding and maintaining sustainable populations on the mines. Nocturnal broadcast surveys on reclaimed mines should also be conducted to determine how mountaintop mining is affecting the nocturnal raptor community.

\section{ACKNOWLEDGEMENTS}

This research was conducted as part of an Environmental Impact Assessment on mountaintop removal mining involving terrestrial vertebrates. Funding was provided by the West Virginia State legislature, while Ark Land Company provided field housing during the 2000 field season. I would also like to thank Arch Coal, Cannelton, and Amherst Corporation for allowing access to their properties. The West Virginia Cooperative Fish and Wildlife Research Unit, USGS, BRD, at West Virginia University provided logistical support and field equipment. Special thanks go to the many people who helped with raptor surveys, especially Dorothy Tinkler and John D. Anderson. Thanks also to Petra Bohall Wood, John W. Edwards, and Roger J. Anderson for helpful comments on this manuscript. 


\section{LITERATURE CITED}

BEDNARZ, J. C., and J. J. DINSMORE. 1981. Status, habitat use, and management of Redshouldered Hawks in Iowa. J. Wildl. Manage. 45: 236-241.

J. C., and J. J. DINSMORE. 1982. Nest-sites and habitat of Red-shouldered and Red-tailed Hawks in Iowa. Wilson Bull. 94: 31-45.

BELLEMAN, B. A. 1998. Red-shouldered Hawk breeding ecology and habitat use in central Minnesota. M. S. Thesis, University of Minnesota, St. Paul. 71 pp.

BENT, A. C. 1937. Life histories of North American birds of prey. Part I. U. S. Natl. Mus. Bull. 167. $409 \mathrm{pp}$.

BILDSTEIN, K. L., and K. MEYER. 2000. Sharp-shinned Hawk (Accipiter striatus). In The Birds of North America, No. 482 (A. Poole and F. Gill, eds.). The Birds of North America, Inc., Philadelphia, PA.

BOHALL, P. G., and M. W. COLLOPY. 1984. Seasonal abundance, habitat use, and perch sites of four raptor species in north-central Florida. J. Field Ornithol. 55: 181-189.

BUCKELEW, A.R. and G.A. HALL. 1994. Red-shouldered Hawk Buteo lineatus. WV Breeding Bird Atlas, University of Pittsburgh Press, Pittsburgh, 215 pp.

BUNN, A. G., W. KLEIN, and K. L. BILDSTEIN. 1995. Time-of-day effects on the numbers and behavior of non-breeding raptors seen on roadside surveys in eastern Pennsylvania. J. Field Ornithol. 66(4): 544-552.

CROCOLL, S. T. 1994. Red-shouldered Hawk (Buteo lineatus). In The Birds of North America, No. 107 (A. Poole and F. Gill, Eds.). Philadelphia: The Academy of Natural Sciences; Washington D.C.: The American Ornithologists' Union.

S. T., and J. W. PARKER. 1989. The breeding biology of Broad-winged and Redshouldered Hawks in western New York. J. Raptor Res. 23: 125-139.

FORREN, J. D. 1981. Artificial perch use by raptors on reclaimed surface mines in West Virginia. M. S. Thesis, West Virginia University, Morgantown. 199 pp.

FULLER, M. R., and J. A. MOSHER. 1987. Raptor survey techniques. Pages 45-46 in B. A. Giron Pendleton, B. A. Millsap, K. W. Cline, and D. M. Bird, eds. Raptor management techniques manual. Natl. Wildl. Fed., Washington D. C.

GOODRICH, L. J., S. C. CROCOLL, and S. E. SENNER. 1996. Broad-winged Hawk (Buteo platypterus). In The Birds of North America, No. 218 (A. Poole and F. Gill, Eds.). 
Philadelphia: The Academy of Natural Sciences; Washington D. C.: The American Ornithologists' Union.

HALL, G. A. 1983. West Virginia Birds: distribution and ecology. Spec. Publ. Carnegie Mus. Nat. Hist. No. 7, Pittsburgh. 180 pp.

HOLT, D. W. and S. M. LEASURE. 1993. Short-eared Owl (Asio flammeus). In The Birds of North America, No. 62 (A. Poole and F. Gill, Eds.). Philadelphia: The Academy of Natural Sciences; Washington D. C.: The American Ornithologists' Union.

JOHNSGARD, P. A. 1990. Hawks, Eagles, and Falcons. Smithsonian Institution, USA.

KENNEDY, P. L. and D. W. STAHLECKER. 1993. Responsiveness of nesting Northern Goshawks to taped broadcasts of three conspecific calls. J. Wildl. Manage. 57(2): 249257.

MAGURRAN, A. E. 1988. Ecological diversity and its measurement. Princeton University Press, Princeton, New Jersey. 179 pp.

MCLEOD, M. A. and D. E. ANDERSON. 1998. Red-shouldered Hawk broadcast surveys: Factors affecting detection of responses and population trends. J. Wildl. Manage. 62(4): 1385-1397.

MINDELL, D. P. 1978. Habitat use by Red-tailed Hawks in surface mined areas. M. S. Thesis, West Virginia University, Morgantown. 98 pp.

MOORMAN, C. E. and B. R. CHAPMAN. 1996. Nest-site selection of Red-shouldered and Redtailed Hawks in a managed forest. Wilson Bull. 108(2): 357-368.

MORRIS, M. M. J., and R. E. LEMON. 1983. Characteristics of vegetation and topography near Red-shouldered Hawk nests in southwestern Quebec. J. Wildl. Manage. 47: 138-145.

MOSHER, J. A., M. R. FULLER, and M. KOPENY. 1990. Surveying woodland raptors by broadcast of conspecific vocalizations. J. Field Ornithol. 61(4): 453-461.

, J. A. and M. R. FULLER. 1996. Surveying woodland hawks with broadcasts of Greathorned Owl vocalizations. Wildl. Soc. Bull. 24(3): 531-536.

PETERSON FIELD GUIDE SERIES. 1990. Peterson Field Guide to Bird Songs of Eastern and Central North America. Cornell Laboratory of Ornithology/Interactive Audio, Houghton Mifflin Co., Boston, Massachusetts.

PORTNOY, J. W., and W. E. DODGE. 1979. Red-shouldered Hawk nesting ecology and behavior. Wilson Bull. 91: 104-117. 
PRESTON, C. R. and R. D. BEANE. 1993. Red-tailed Hawk (Buteo jamaicensis). In The Birds of North America, No. 52 (A. Poole and F. Gill, Eds.). Philadelphia: The Academy of Natural Sciences; Washington, D. C.: The American Ornithologists' Union.

ROHRBAUGH, R. W., Jr. and R. H. YAHNER. 1996. Reclaimed surface mines: an important nesting habitat for Northern Harriers in Pennsylvania. Pp. 307-314 in D. M. Bird, D. E. Varland, and J. J. Negro (eds.), Raptors in human landscapes. Academic Press, London, U. K.

ROSENFIELD, R. N., and J. BIELEFELDT. 1993. Cooper's Hawk (Accipiter cooperii). In The Birds of North America, No. 75 (A. Poole and F. Gill, Eds.). Philadelphia: The Academy of Natural Sciences; Washington, D. C.: The American Ornithologists' Union.

R. N., J. BIELEFELDT, and R. K. ANDERSON. 1988. Effectiveness of broadcast calls for detecting breeding Cooper's Hawks. Wildl. Soc. Bull. 16(2): 210-212.

SAS INSTITUTE INC. 1991. SAS/STAT Guide for personal computers, version 6 edition. SAS Institute, Inc. Cary, North Carolina, 1028 pp.

STRAUSBAUGH. P. D. and E. L. CORE. 1977. Flora of West Virginia. Seneca Books Inc., Morgantown, West Virginia, 1079 pp.

TITUS, K., and J. A. MOSHER. 1981. Nest-site habitat selected by woodland hawks in the central Appalachians. Auk 98: 270-281.

YAHNER, R. H. and R. W. ROHRBAUGH, Jr. 1998. A comparison of raptor use of reclaimed surface mines and agricultural habitats in Pennsylvania. J. Raptor Res. 32(2): 178-180. 
Table 2.1. Number of raptor broadcast surveys across treatments within stream drainages across three mine sites in southern West Virginia, February 2000-January 2001.

\begin{tabular}{|c|c|c|c|c|c|}
\hline \multirow[b]{2}{*}{ Replication } & \multicolumn{4}{|c|}{ Treatment } & \multirow[b]{2}{*}{ TOTAL } \\
\hline & Grassland & Shrub/pole & $\begin{array}{c}\text { Fragmented } \\
\text { Forest }\end{array}$ & Intact Forest & \\
\hline \multicolumn{6}{|l|}{ Hobet mine } \\
\hline Lavender Fork & 1 & & & & \\
\hline Big Horse & 1 & & 2 & & \\
\hline Stanley Fork & 2 & & 2 & & \\
\hline Long Branch & & 4 & & & \\
\hline Hill Fork & & 2 & & & \\
\hline Big Buck Fork & & & & 3 & \\
\hline Spring Branch & & & & 2 & \\
\hline & 4 & 6 & 4 & 5 & 19 \\
\hline
\end{tabular}

Daltex mine

Beech Creek

4

Rockhouse Creek 4

Pigeonroost Branch 2

\begin{tabular}{llllll} 
Big Bend Creek & \multicolumn{3}{c}{2} & \\
\cline { 2 - 5 } & 4 & 0 & 4 & 4 & 12
\end{tabular}

Cannelton mine

\begin{tabular}{rccccc} 
Bullpush Fork & 4 & 6 & & & \\
$\begin{array}{r}\text { Hughes Fork } \\
\text { Ash Fork }\end{array}$ & & 4 & 3 & \\
\cline { 2 - 6 } & 4 & 6 & 4 & 3 & 17 \\
& 12 & 12 & 12 & 12 & $\mathbf{4 8}$ \\
\hline
\end{tabular}


Table 2.2. Mean abundance and standard error (SE) for raptor species observed on broadcast surveys across 4 treatments during February 2000-January 2001 in southern West Virginia. Within a row, treatments with the same letter do not differ at $\alpha=0.10$ with Waller-Duncan K-ratio $t$-tests.

\begin{tabular}{|c|c|c|c|c|c|c|c|c|c|c|c|c|c|c|c|}
\hline \multirow[b]{3}{*}{ Species } & \multirow[b]{3}{*}{ Season } & \multicolumn{12}{|c|}{ Treatment } & \multirow[b]{3}{*}{$F$} & \multirow[b]{3}{*}{$P$-value } \\
\hline & & \multicolumn{3}{|c|}{ Grassland } & \multicolumn{3}{|c|}{ Shrub/pole } & \multicolumn{3}{|c|}{ Fragmented forest } & \multicolumn{3}{|c|}{ Intact forest } & & \\
\hline & & Mean & & $\mathrm{SE}$ & Mean & & SE & Mean & & SE & Mean & & SE & & \\
\hline American Kestrel & & 0.06 & $\mathrm{~A}$ & 0.02 & 0.00 & $\mathrm{~B}$ & 0.00 & 0.00 & $\mathrm{~B}$ & 0.00 & 0.00 & $\mathrm{~B}$ & 0.00 & 6.26 & 0.0003 \\
\hline Peregrine Falcon & & 0.01 & & 0.01 & 0.00 & & 0.00 & 0.00 & & 0.00 & 0.00 & & 0.00 & 0.96 & 0.4117 \\
\hline Cooper's Hawk & & 0.01 & & 0.01 & 0.00 & & 0.00 & 0.00 & & 0.00 & 0.00 & & 0.00 & 0.96 & 0.4117 \\
\hline Accipiter spp. ${ }^{\mathrm{a}}$ & & 0.00 & & 0.00 & 0.01 & & 0.01 & 0.00 & & 0.00 & 0.00 & & 0.00 & 0.96 & 0.4117 \\
\hline \multirow[t]{3}{*}{ Northern Harrier } & $\mathrm{M}^{\mathrm{b}}$ & 0.13 & $\mathrm{~A}$ & 0.05 & 0.00 & $\mathrm{~B}$ & 0.00 & 0.00 & B & 0.00 & 0.00 & $\mathrm{~B}$ & 0.00 & 6.19 & 0.0005 \\
\hline & $\mathrm{S}$ & 0.04 & & 0.03 & 0.02 & & 0.02 & 0.00 & & 0.00 & 0.00 & & 0.00 & 1.24 & 0.2966 \\
\hline & $\mathrm{W}$ & 0.25 & A & 0.07 & 0.00 & B & 0.00 & 0.00 & B & 0.00 & 0.00 & B & 0.00 & 12.28 & $<0.0001$ \\
\hline Red-tailed Hawk & & 0.07 & & 0.03 & 0.01 & & 0.01 & 0.07 & & 0.02 & 0.03 & & 0.02 & 1.86 & 0.1352 \\
\hline Red-shouldered Hawk & & 0.01 & $\mathrm{~B}$ & 0.01 & $0.03 \mathrm{I}$ & BA & 0.01 & 0.03 & BA & 0.01 & 0.07 & $\mathrm{~A}$ & 0.03 & 2.57 & 0.0532 \\
\hline Eastern screech Owl & & 0.00 & & 0.00 & 0.02 & & 0.01 & 0.03 & & 0.02 & 0.00 & & 0.00 & 1.79 & 0.1478 \\
\hline Barred Owl & & 0.00 & & 0.00 & 0.00 & & 0.00 & 0.00 & & 0.00 & 0.01 & & 0.01 & 0.87 & 0.4545 \\
\hline \multirow[t]{3}{*}{ Turkey Vulture } & M & 0.31 & & 0.14 & 0.44 & & 0.27 & 0.00 & & 0.00 & 0.00 & & 0.00 & 1.94 & 0.1247 \\
\hline & $S$ & 0.94 & $\mathrm{~A}$ & 0.30 & 0.19 & $\mathrm{~B}$ & 0.09 & 0.10 & $\mathrm{~B}$ & 0.07 & 0.02 & $\mathrm{~B}$ & 0.02 & 7.01 & 0.0002 \\
\hline & $\mathrm{W}$ & 0.13 & & 0.13 & 0.04 & & 0.04 & 0.02 & & 0.02 & 0.10 & & 0.06 & 0.43 & 0.7297 \\
\hline Unknown & & 0.01 & & 0.01 & 0.00 & & 0.00 & 0.00 & & 0.01 & 0.02 & & 0.11 & 0.53 & 0.6600 \\
\hline
\end{tabular}

${ }^{\mathrm{a}}$ Either Sharp-shinned Hawk or Cooper's Hawk.

${ }^{\mathrm{b}}$ ANOVA indicated a significant interaction between treatment and season, so seasons were analyzed separately (M=Migration, $\mathrm{S}=\mathrm{Summer}$, W=Winter). 
Table 2.3. Abundance and richness of raptor species observed on roadside surveys for 3 treatment types during July and December 2000 on mines in southern West Virginia.

\begin{tabular}{|c|c|c|c|c|c|c|c|c|c|}
\hline \multirow[b]{2}{*}{ Species } & \multicolumn{3}{|c|}{ Hobet } & \multicolumn{3}{|c|}{ Cannelton } & \multicolumn{3}{|c|}{ Daltex } \\
\hline & Grassland & $\begin{array}{c}\text { Shrub/ } \\
\text { pole }\end{array}$ & $\begin{array}{c}\text { Fragmented } \\
\text { Forest }\end{array}$ & Grassland & $\begin{array}{c}\text { Shrub/ } \\
\text { pole }\end{array}$ & $\begin{array}{c}\text { Fragmented } \\
\text { Forest }\end{array}$ & Grassland & & $\begin{array}{l}\text { ragmented } \\
\text { Forest }\end{array}$ \\
\hline American Kestrel & $\overline{5}$ & 0 & 0 & & 0 & 0 & 5 & 5 & $\overline{0}$ \\
\hline Peregrine Falcon & 0 & 0 & 0 & & 0 & 0 & 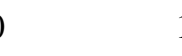 & 1 & 0 \\
\hline Northern Harrier & 4 & 0 & 0 & & 1 & 1 & ) & 1 & 0 \\
\hline Broad-winged Hawk & 0 & 0 & 0 & & 0 & 0 & . & 0 & 0 \\
\hline Red-tailed Hawk & 2 & 1 & 0 & & 3 & 0 & + & 1 & 1 \\
\hline Rough-legged Hawk & 1 & 0 & 0 & & 0 & 0 & ( & 0 & 0 \\
\hline Turkey Vulture & 6 & 6 & 2 & & 0 & 0 & ( & 5 & 11 \\
\hline Unknown & 1 & 0 & 0 & & 0 & 1 & b & 1 & 0 \\
\hline Overall Abundance & 19 & 7 & 2 & & 5 & 2 & 7 & & 12 \\
\hline Overall Richness & 5 & 2 & 1 & & 3 & 1 & 3 & 5 & 2 \\
\hline
\end{tabular}


Table 2.4. Seasonal observations of raptor species ( $\mathrm{w}=$ winter, $\mathrm{s}=$ summer, $\mathrm{m}=$ migration) on the three mines in each of the four treatments (GR=Grassland, $\mathrm{SH}=$ Shrub/pole, FR=Fragmented forest, IN=Intact forest), compared to species expected to occur based on habitat requirements and West Virginia Breeding Bird Atlas (WVBBA) records.

\begin{tabular}{|c|c|c|c|c|c|c|c|c|c|c|c|c|c|c|c|c|}
\hline \multirow{3}{*}{ Species } & \multirow{3}{*}{$\begin{array}{l}\text { WVBBA } \\
\text { record }\end{array}$} & \multicolumn{4}{|c|}{$\begin{array}{l}\text { Expected in WV from } \\
\text { habitat requirements }\end{array}$} & \multicolumn{11}{|c|}{ Observations on the 3 mines $^{b}$} \\
\hline & & \multirow[b]{2}{*}{ GR } & \multirow[b]{2}{*}{ SH } & \multirow[b]{2}{*}{ FR } & \multirow[b]{2}{*}{ IN } & \multicolumn{4}{|c|}{ Hobet } & \multicolumn{3}{|c|}{ Daltex } & \multicolumn{4}{|c|}{ Cannelton } \\
\hline & & & & & & GR & SH & FR & IN & GR & FR & IN & GR & SH & FR & IN \\
\hline American Kestrel & $\overline{\mathrm{s}}$ & wsm & wsm & wm & wm & wsm & & $\mathrm{m}$ & & $\mathrm{sm}$ & & & ws & $\mathrm{sm}$ & & \\
\hline Peregrine Falcon & & $\mathrm{m}$ & & & & & & & & $\mathrm{sm}$ & & & $\mathrm{sm}$ & w & & \\
\hline Northern Harrier & & $\mathrm{m}$ & & & & wsm & & & & wsm & & & wsm & $\mathrm{sm}$ & & \\
\hline Broad-winged Hawk & $\mathrm{s}$ & & & & $\mathrm{sm}$ & $\mathrm{s}$ & & & & & & $\mathrm{s}$ & & & $\mathrm{sm}$ & \\
\hline Red-shouldered Hawk & $\mathrm{s}$ & & & & wsm & $\mathrm{s}$ & wsm & $\mathrm{sm}$ & wsm & ws & $\mathrm{m}$ & $\mathrm{s}$ & & wsm & wsm & wsm \\
\hline Red-tailed Hawk & $\mathrm{s}$ & $\mathrm{s}$ & $\mathrm{s}$ & wsm & wsm & wsm & wsm & wsm & wsm & wsm & ws & $\mathrm{sm}$ & wsm & wsm & $\mathrm{sm}$ & \\
\hline Rough-legged Hawk & & & & $\mathrm{mw}$ & $\mathrm{mw}$ & $\mathrm{w}$ & & $\mathrm{w}$ & & & & & & & & \\
\hline Cooper's Hawk & $\mathrm{s}$ & s & $\mathrm{s}$ & $\mathrm{sm}$ & $\mathrm{sm}$ & $\mathrm{m}$ & & & & $\mathrm{m}$ & & $\mathrm{s}$ & $\mathrm{m}$ & & & \\
\hline Sharp-shinned Hawk & $\mathrm{s}$ & & $\mathrm{s}$ & $\mathrm{sm}$ & $\mathrm{sm}$ & $\mathrm{s}$ & & & & & & & & w & & \\
\hline Accipiter spp. ${ }^{\mathrm{c}}$ & $\mathrm{s}$ & $\mathrm{s}$ & $\mathrm{s}$ & $\mathrm{sm}$ & $\mathrm{sm}$ & & & $\mathrm{s}$ & & & $\mathrm{w}$ & & & & & \\
\hline Barred Owl & $\mathrm{s}$ & & $\mathrm{s}$ & wsm & wsm & & & $\mathrm{s}$ & $\mathrm{s}$ & & & $\mathrm{s}$ & & $\mathrm{w}$ & & \\
\hline Eastern screech Owl & $\mathrm{s}$ & & $\mathrm{s}$ & wsm & wsm & & wm & $\mathrm{s}$ & & & wsm & & & w & $\mathrm{w}$ & \\
\hline Short-eared Owl & & wm & & & & $\mathrm{s}$ & & & & ws & & & ws & & & \\
\hline Turkey Vulture & $\mathrm{s}$ & wsm & wsm & wsm & $\mathrm{s}$ & $\mathrm{sm}$ & wsm & s & wsm & $\mathrm{sm}$ & Ws & & wsm & $\mathrm{sm}$ & wsm & \\
\hline
\end{tabular}



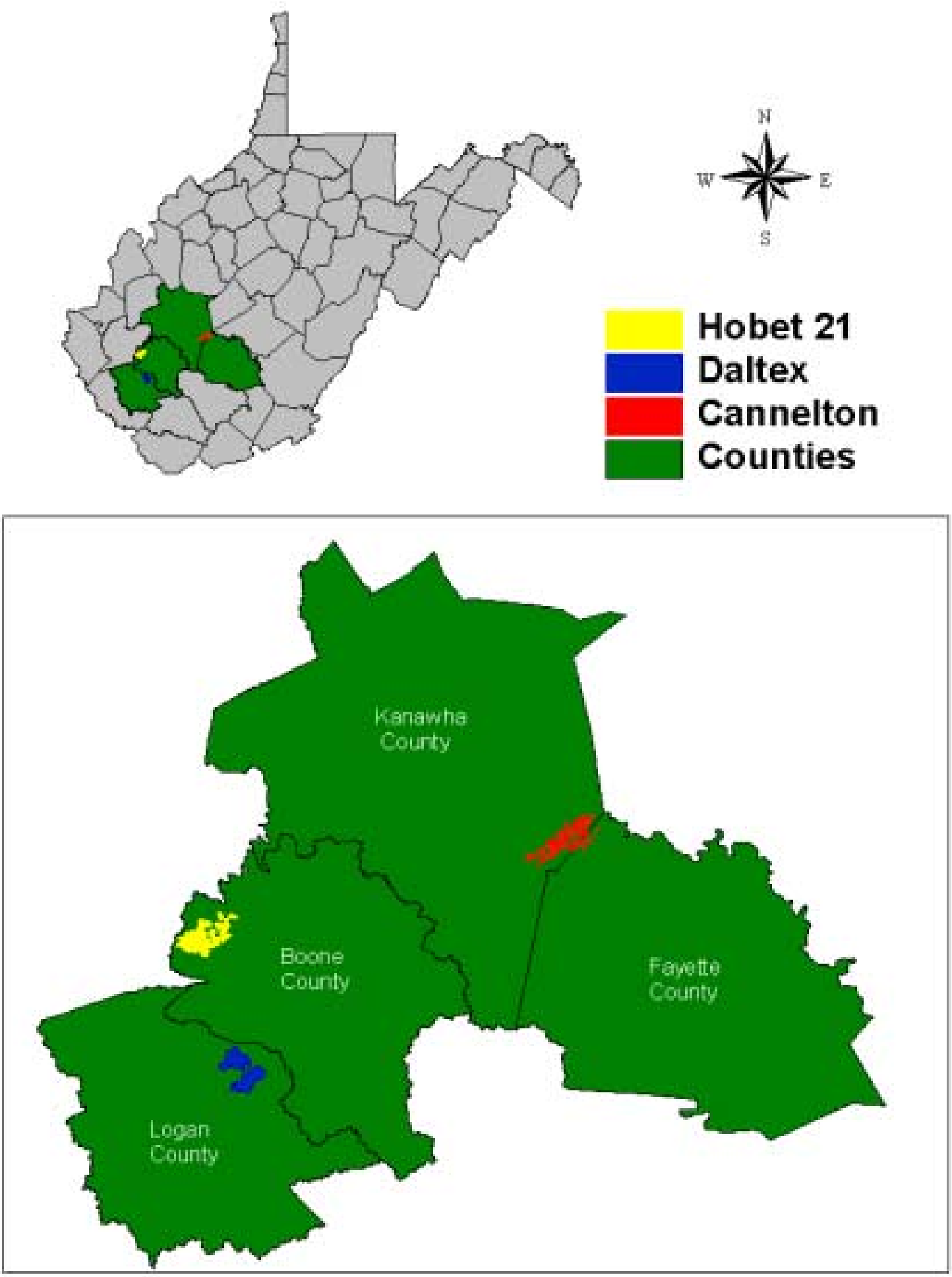

Figure 2.1. Location of mountaintop removal/valley fill mine sites in southern West Virginia, February 2000-January 2001. 


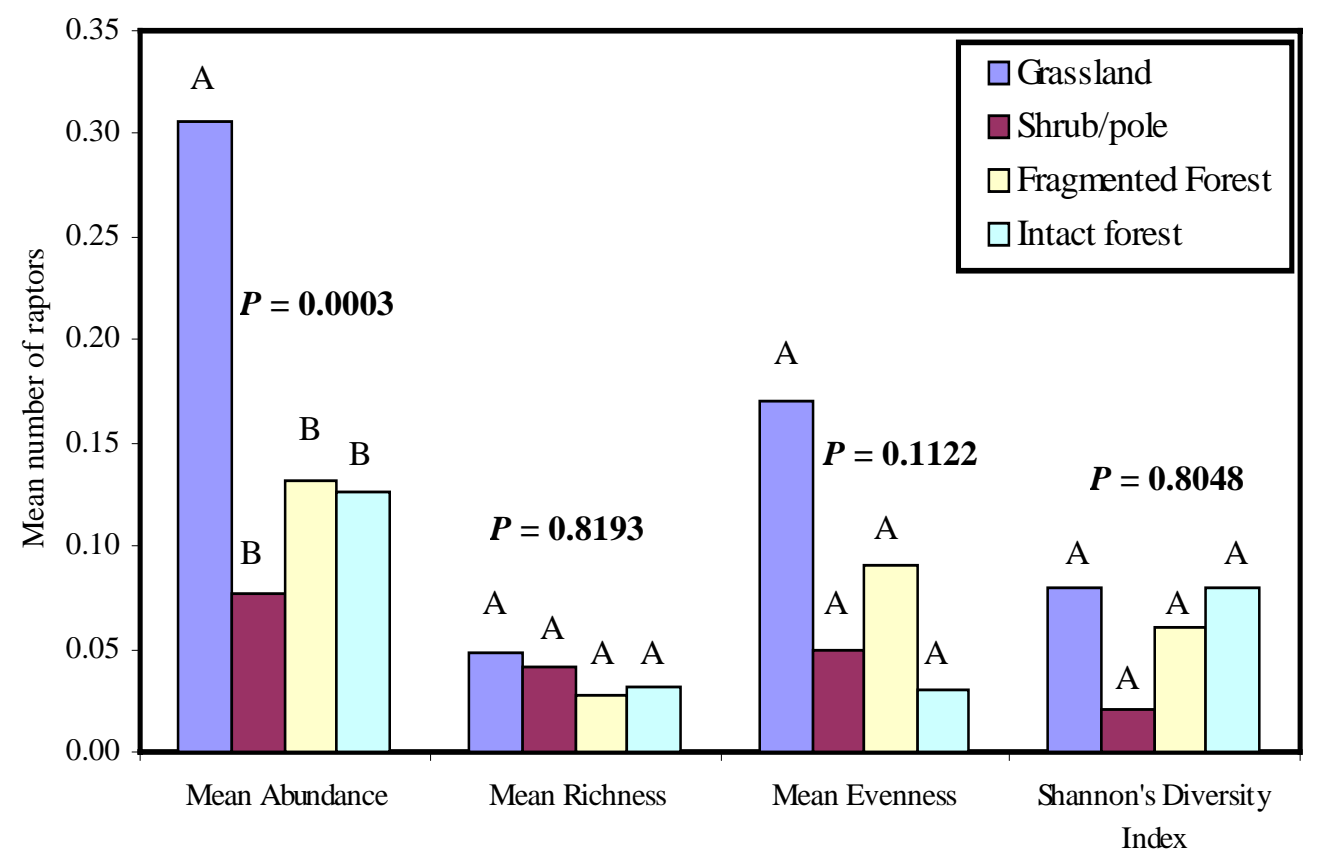

Figure 2.2. Comparison of mean abundance, richness, evenness, and Shannon's diversity index for raptors detected during broadcast surveys across 4 treatments in southern West Virginia, Febuary 2000-January 2001. Treatments with the same letter do not differ at $\alpha=0.1$. 


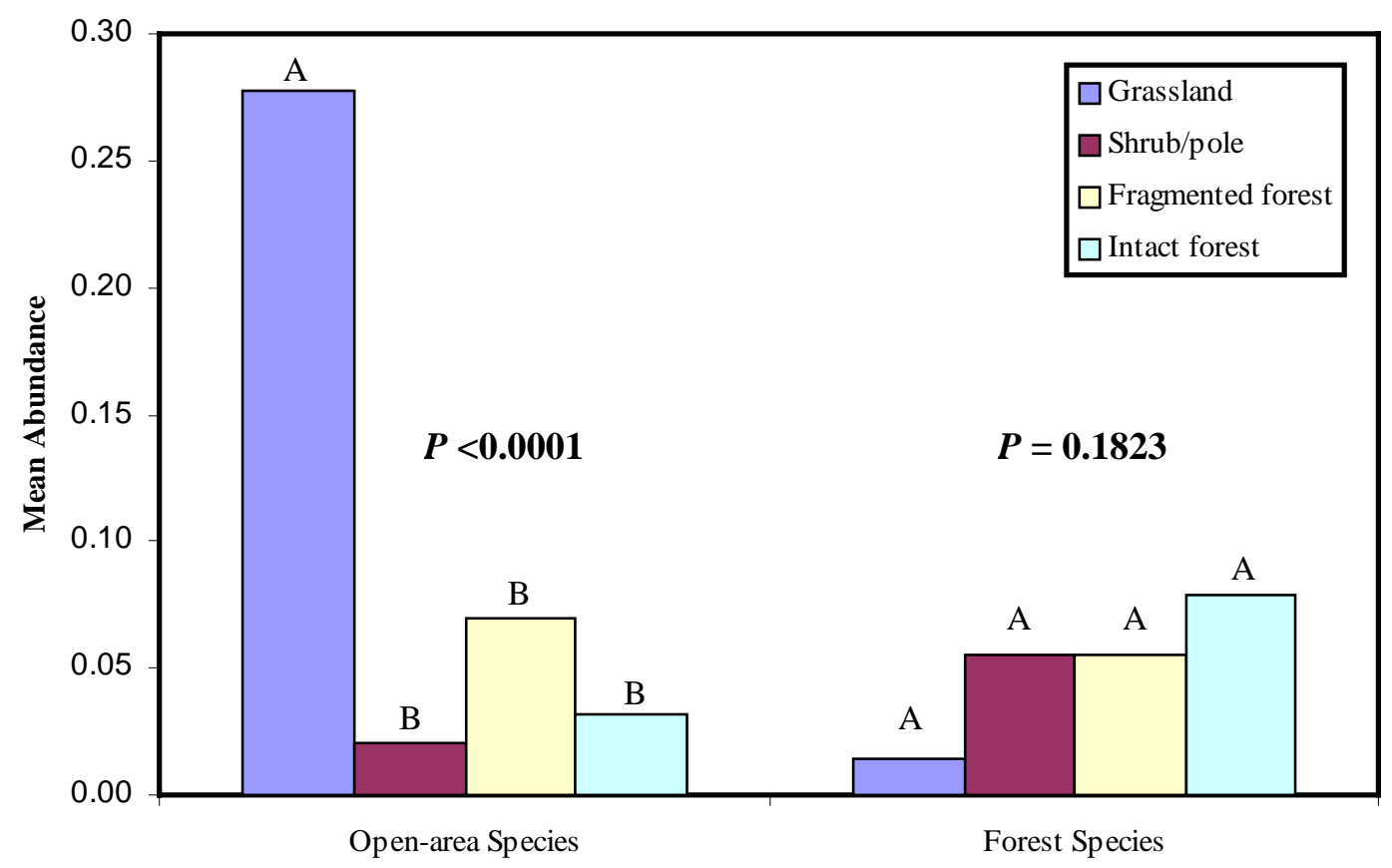

Figure 2.3. Mean abundance of open-area raptor species (American Kestrel, Peregrine Falcon, Northern Harrier, and Red-tailed Hawk) and forest raptor species (Cooper's Hawk, Accipiter spp., Red-shouldered Hawk, Eastern Screech Owl, and Barred Owl) detected on broadcast surveys across 4 treatments in southern West Virginia, February 2000-January 2001. Treatments with the same letter do not differ at the $\alpha=0.1$. 
A

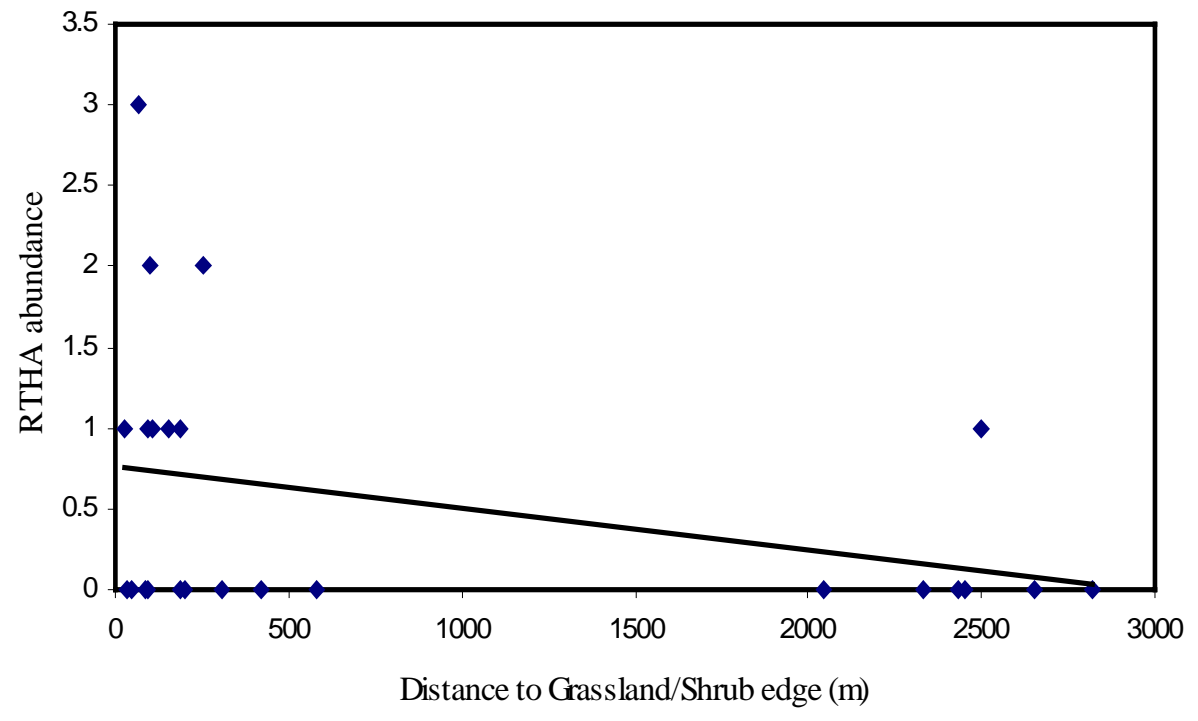

B

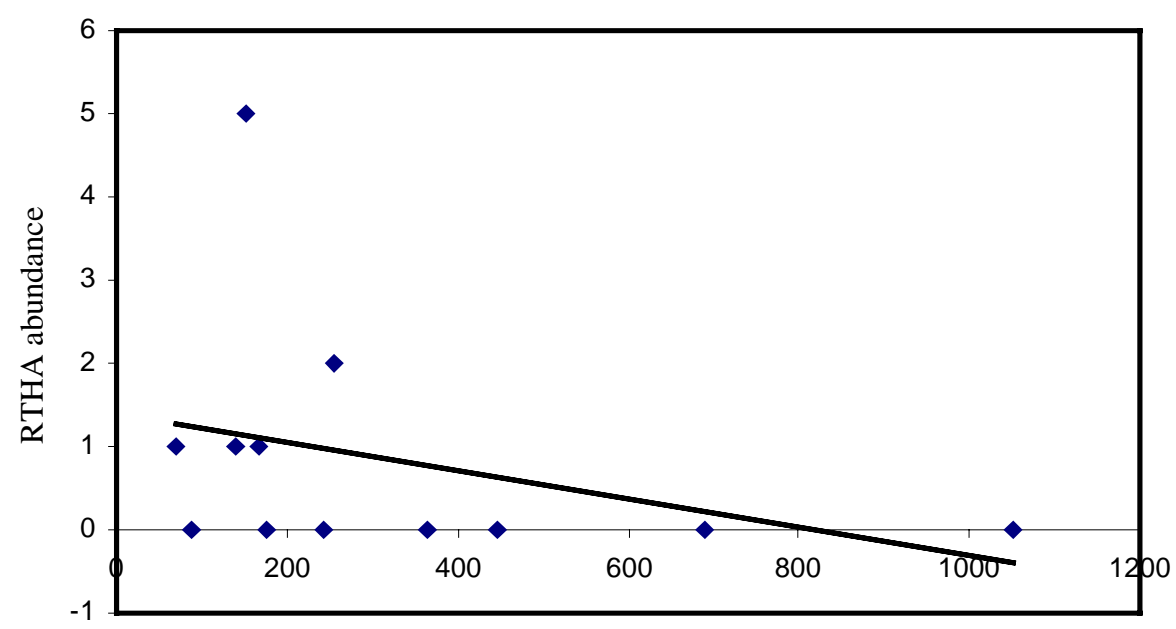

Distance to forest edge $(\mathrm{m})$

Figure 2.4. Relationship of Red-tailed Hawk abundance and distance to grassland/shrub edge for points within the fragmented and intact forest treatments (A), and relationship of Red-tailed Hawk abundance and distance to forest edge for points within the grassland treatment (B). 
Appendix Table 2.1. Mean decibel level readings taken before and after leaf-out in each of the four treatments in southern West Virginia at distances of 1, 30, and $50 \mathrm{~m}$ from speakerphone.

\begin{tabular}{|c|c|c|c|c|c|c|}
\hline \multirow[b]{2}{*}{ Treatment } & \multirow[b]{2}{*}{ Point } & \multirow[b]{2}{*}{ Distance (m) } & \multicolumn{2}{|c|}{ Prior to leaf-out (db) } & \multicolumn{2}{|c|}{ After leaf-out (db) } \\
\hline & & & RSHA $^{\mathbf{a}}$ & GHOW $^{b}$ & RSHA & GHOW \\
\hline \multirow[t]{3}{*}{ Grassland } & 92 & 1 & 106.5 & 90 & 101.5 & 89.5 \\
\hline & & 30 & 68 & 56 & 77 & 62 \\
\hline & & 50 & 62 & $<50$ & 67 & 54 \\
\hline \multirow[t]{3}{*}{ Shrub/pole } & 160 & 1 & 102.5 & 86.5 & 104 & 88 \\
\hline & & 30 & 78 & 58 & 79.5 & 56 \\
\hline & & 50 & 68 & 58 & 72 & 55 \\
\hline Fragmented & 94 & 1 & 106.5 & 95.5 & 103 & 90 \\
\hline \multirow[t]{2}{*}{ Forest } & & 30 & 78 & 69 & 69.5 & 60 \\
\hline & & 50 & 69 & 58.5 & 64 & 54 \\
\hline \multirow[t]{3}{*}{ Intact Forest } & 85 & 1 & 102.5 & 88.5 & 104 & 94 \\
\hline & & 30 & 69 & 56 & 71 & 61 \\
\hline & & 50 & 68 & 52 & 62.5 & 58 \\
\hline
\end{tabular}

${ }^{\mathrm{a}}$ Red-shouldered Hawk

${ }^{\mathrm{b}}$ Great-horned Owl 
Appendix Table 2.2. Seasonal mean abundance and species richness of raptors during broadcast surveys across the four treatments in southern West Virginia, February 2000-January 2001.

\begin{tabular}{|c|c|c|c|c|c|c|c|c|c|c|c|c|}
\hline \multirow[b]{3}{*}{ Species } & \multicolumn{6}{|c|}{ Grassland } & \multicolumn{6}{|c|}{ Shrub/pole } \\
\hline & \multicolumn{2}{|c|}{ Winter } & \multicolumn{2}{|c|}{ Summer } & \multicolumn{2}{|c|}{ Migration } & \multicolumn{2}{|c|}{ Winter } & \multicolumn{2}{|c|}{ Summer } & \multicolumn{2}{|c|}{ Migration } \\
\hline & Mean & SE & Mean & SE & Mean & SE & Mean & SE & Mean & SE & Mean & SE \\
\hline American Kestrel & 0.02 & 0.02 & 0.04 & 0.03 & 0.13 & 0.06 & 0.00 & 0.00 & 0.00 & 0.00 & 0.00 & 0.00 \\
\hline Peregrine Falcon & 0.00 & 0.00 & 0.00 & 0.00 & 0.02 & 0.02 & 0.00 & 0.00 & 0.00 & 0.00 & 0.00 & 0.00 \\
\hline Cooper's Hawk & 0.00 & 0.00 & 0.00 & 0.00 & 0.02 & 0.02 & 0.00 & 0.00 & 0.00 & 0.00 & 0.00 & 0.00 \\
\hline Accipiter spp..$^{a}$ & 0.00 & 0.00 & 0.00 & 0.00 & 0.00 & 0.00 & 0.02 & 0.02 & 0.00 & 0.00 & 0.00 & 0.00 \\
\hline Northerı & 0.25 & 0.07 & 0.04 & 0.03 & 0.13 & 0.05 & 0.00 & 0.00 & 0.02 & 0.02 & 0.00 & 0.00 \\
\hline Red-tailed Hawk & 0.06 & 0.06 & 0.08 & 0.04 & 0.06 & 0.04 & 0.02 & 0.02 & 0.02 & 0.02 & 0.00 & 0.00 \\
\hline Red-shouldered Hawk & 0.02 & 0.02 & 0.00 & 0.00 & 0.00 & 0.00 & 0.04 & 0.03 & 0.00 & 0.00 & 0.04 & 0.03 \\
\hline Eastern screech Owl & 0.00 & 0.00 & 0.00 & 0.00 & 0.00 & 0.00 & 0.04 & 0.03 & 0.00 & 0.00 & 0.02 & 0.02 \\
\hline Barred Owl & 0.00 & 0.00 & 0.00 & 0.00 & 0.00 & 0.00 & 0.00 & 0.00 & 0.00 & 0.00 & 0.00 & 0.00 \\
\hline Turkey Vulture & 0.13 & 0.13 & 0.94 & 0.30 & 0.31 & 0.14 & 0.04 & 0.04 & 0.19 & 0.09 & 0.44 & 0.27 \\
\hline Unknown & 0.04 & 0.04 & 0.00 & 0.00 & 0.00 & 0.00 & 0.00 & 0.00 & 0.00 & 0.00 & 0.00 & 0.00 \\
\hline Overall Abundance & 0.52 & 0.16 & 1.10 & 0.30 & 0.67 & 0.16 & 0.17 & 0.07 & 0.23 & 0.10 & 0.46 & 0.27 \\
\hline Overall Richness & 0.10 & 0.04 & 0.08 & 0.04 & 0.13 & 0.05 & 0.10 & 0.05 & 0.06 & 0.05 & 0.06 & 0.04 \\
\hline
\end{tabular}

${ }^{a}$ Either Sharp-shinned Hawk or Cooper's Hawk 
Appendix Table 2.2 continued.

\begin{tabular}{|c|c|c|c|c|c|c|c|c|c|c|c|c|}
\hline \multirow[b]{3}{*}{ Species } & \multicolumn{6}{|c|}{ Fragmented forest } & \multicolumn{6}{|c|}{ Intact forest } \\
\hline & \multicolumn{2}{|c|}{ Winter } & \multicolumn{2}{|c|}{ Summer } & \multicolumn{2}{|c|}{ Migration } & \multicolumn{2}{|c|}{ Winter } & \multicolumn{2}{|c|}{ Summer } & \multicolumn{2}{|c|}{ Migration } \\
\hline & Mean & $\mathrm{SE}$ & Mean & $\mathrm{SE}$ & Mean & SE & Mean & $\mathrm{SE}$ & Mean & $\mathrm{SE}$ & Mean & SE \\
\hline American Kestrel & 0.00 & 0.00 & 0.00 & 0.00 & 0.00 & 0.00 & 0.00 & 0.00 & 0.00 & 0.00 & 0.00 & 0.00 \\
\hline Peregrine Falcon & 0.00 & 0.00 & 0.00 & 0.00 & 0.00 & 0.00 & 0.00 & 0.00 & 0.00 & 0.00 & 0.00 & 0.00 \\
\hline Cooper's hawk & 0.00 & 0.00 & 0.00 & 0.00 & 0.00 & 0.00 & 0.00 & 0.00 & 0.00 & 0.00 & 0.00 & 0.00 \\
\hline Accipiter spp. ${ }^{a}$ & 0.00 & 0.00 & 0.00 & 0.00 & 0.00 & 0.00 & 0.00 & 0.00 & 0.00 & 0.00 & 0.00 & 0.00 \\
\hline Northern Harrier & 0.00 & 0.00 & 0.00 & 0.00 & 0.00 & 0.00 & 0.00 & 0.00 & 0.00 & 0.00 & 0.00 & 0.00 \\
\hline Red-tailed hawk & 0.13 & 0.06 & 0.06 & 0.04 & 0.02 & 0.02 & 0.02 & 0.02 & 0.02 & 0.02 & 0.05 & 0.04 \\
\hline Red-shouldered Hawk & 0.00 & 0.00 & 0.02 & 0.02 & 0.06 & 0.04 & 0.02 & 0.02 & 0.08 & 0.05 & 0.11 & 0.06 \\
\hline Eastern screech Owl & 0.04 & 0.04 & 0.00 & 0.00 & 0.04 & 0.03 & 0.00 & 0.00 & 0.00 & 0.00 & 0.00 & 0.00 \\
\hline Barred Owl & 0.00 & 0.00 & 0.00 & 0.00 & 0.00 & 0.00 & 0.00 & 0.00 & 0.02 & 0.02 & 0.00 & 0.00 \\
\hline Turkey Vulture & 0.02 & 0.02 & 0.10 & 0.07 & 0.00 & 0.00 & 0.10 & 0.06 & 0.02 & 0.02 & 0.00 & 0.00 \\
\hline Unknown & 0.00 & 0.00 & 0.02 & 0.02 & 0.00 & 0.00 & 0.02 & 0.02 & 0.02 & 0.02 & 0.00 & 0.00 \\
\hline Overall Abundance & 0.19 & 0.07 & 0.21 & 0.08 & 0.13 & 0.06 & 0.17 & 0.08 & 0.17 & 0.08 & 0.16 & 0.07 \\
\hline Overall Richness & 0.06 & 0.04 & 0.06 & 0.04 & 0.06 & 0.05 & 0.07 & 0.05 & 0.08 & 0.04 & 0.05 & 0.04 \\
\hline
\end{tabular}

${ }^{a}$ Either Sharp-shinned Hawk or Cooper's Hawk 


\section{CHAPTER 3:}

\section{HABITAT CHARACTERISTICS OF RED-SHOULDERED HAWKS (BUTEO LINEATUS) IN A RECLAIMED MINE LANDSCAPE AT MICROHABITAT AND LANDSCAPE SCALES}




\section{ABSTRACT}

Fragmentation of the landscape by large-scale mining may have negative effects on Redshouldered Hawk (Buteo lineatus) populations by reducing the amount of forested habitat and creating fragmented forest patches surrounded by reclaimed mine lands. The habitat characteristics of Red-shouldered Hawks in reclaimed mine landscapes was examined at both landscape and microhabitat scales within four treatments: early-successional grassland habitat, mid-successional shrub/pole habitat, late-successional fragmented forest habitat, and latesuccessional intact forest habitat. Forty-eight stations on and adjacent to three mines were surveyed using standardized broadcast call techniques during February 2000-January 2001. Microhabitat characteristics were quantified within an $11.3 \mathrm{~m}$ radius plot centered on each of 48 stations, while landscape characteristics within 1000 and $564 \mathrm{~m}$ buffer zones around each station were measured from digitized aerial photographs. All variables were tested by stepwise logistic and multiple linear regression to determine the best-fit habitat models for Red-shouldered Hawks. Within the 1000-m zone, amount of wetland was the most important habitat characteristic determining presence of Red-shouldered Hawks in a forest-dominated landscape. The percentage of coarse woody debris on the ground was the best microhabitat indicator for higher abundance of Red-shouldered Hawks at forested points. More Red-shouldered Hawks were observed in forested habitats with a greater distance to microhabitat edge. More coarse woody debris in combination with more wetlands in the landscape, may provide for a large source population of amphibians and reptiles, important in the diet of Red-shouldered Hawks.

Keywords: $\quad$ Red-shouldered Hawk, Buteo lineatus, mining, raptors, macrohabitat, microhabitat. 


\section{INTRODUCTION}

The eastern subspecies of the Red-shouldered Hawk (Buteo lineatus lineatus) is considered primarily a forest species that breeds in large tracts of contiguous, mature forest (Hall 1983, Buckelew and Hall 1994, Crocoll 1994). Although quantitative data are lacking, trends suggest a long-term decline in the numbers of Red-shouldered Hawks (Peterson and Crocoll 1992). Three states list this species as endangered (New Jersey, Illinois, and Iowa), three states as threatened (New York, Michigan, and Wisconsin), and five states as special concern (Connecticut, Minnesota, Mississippi, Nebraska, and Indiana) (Crocoll 1994). A number of states have attributed the decline primarily to reduction of closed canopy forest due to logging, agriculture, urban development, and drainage of wooded wetlands, and secondarily to competition with Red-tailed Hawks (Buteo jamaicensis) (Peterson and Crocoll 1992). The status of Red-shouldered Hawk populations in West Virginia is thought to be stable with breeding confirmed in 34 Breeding Bird survey blocks in the state and a majority of the state consisting of mature forest (Buckelew and Hall 1994).

Nest site selection studies of Red-shouldered Hawks have concluded that they select large, even-aged, mature stands of deciduous trees that have a well developed canopy layer and reduced understory (Portnoy and Dodge 1979, Titus and Mosher 1981, Bednarz and Dinsmore 1981, 1982, Morris and Lemon 1983, Bloom et al. 1993, McLeod 1996, Moorman and Chapman 1996, Belleman 1998). Nest sites have also been associated with floodplain forest within close range of open water (Bent 1937, Titus and Mosher 1981, Bednarz and Dinsmore 1981, 1982, Moorman and Chapman 1996). Other studies have shown Red-shouldered Hawks to nest in upland, hardwood forests rather than floodplain forest, but were still in close proximity to water (Crocoll and Parker 1989, Belleman 1998). Bednarz and Dinsmore (1982) found that Redshouldered Hawks in Iowa used upland forest habitat, but use was limited to areas immediately 
adjacent to floodplains, so they suggested that upland forest may be used when floodplain forest is not adequately available.

No previous studies have examined the effect of mountaintop removal mining on Redshouldered Hawks, although the loss and fragmentation of forest and creation of edge by the mountaintop mining process may have negative effects on this species. In a study on 12 reclaimed surface mines in northern West Virginia and southern Pennsylvania, Mindell (1978) noted that although American Kestrels and Red-tailed Hawks were relatively common, other raptor species such as Red-shouldered Hawks were much less common. On reclaimed surface mines in northern West Virginia, Forren (1981) found no Red-shouldered Hawks using artificial perches, nor any mention of them on the surface mine at any time. In these studies, reclaimed mines were approximately $0.7-40$ ha in size, while mountaintop mines typically are much larger and encompass hundreds of hectares. Moorman and Chapman (1996) found Red-shouldered Hawks nesting significantly further away from edges than Red-tailed Hawks. Creation of edge also may increase competition from Red-tailed Hawks for nesting (Bednarz and Dinsmore 1982, Moorman and Chapman 1996). To determine the impact relatively large-scale mountaintop removal mines are having on forest raptor populations, the major objective of the study was to determine the micro and macrohabitat characteristics important to Red-shouldered Hawks in southern West Virginia.

\section{STUDY AREA}

Study areas were associated with three mountaintop removal mines located in southern West Virginia. Hobet 21 mine located in the Mud River drainage basin in Boone County was the largest site at approximately 2,431 ha. At approximately 1,819 ha., the Daltex mine located in the Spruce Fork drainage basin in Logan County was the smallest. The Cannelton mine 
approximately 2,180 ha in size, was located in the Twentymile Creek drainage basin along the border of Kanawha and Fayette Counties. Study areas were divided into four treatments: intact forest, fragmented forest, young reclaimed mine (grassland), and older reclaimed mine (shrub/pole). Intact forest was mature forest located adjacent to the mines, but undisturbed by mining activities and located within the same river drainage basin. Fragmented forest was a forest tract almost entirely surrounded by reclaimed mine land. Grassland areas were estimated to be 5-19 years of age and consisted of mostly grasses and scattered shrubs. Shrub/pole areas were made up of shrub and pole-sized vegetation and ranged from 13-27 years of age.

The intact and fragmented forest areas were comprised of mature Appalachian hardwood species typical of mixed mesophytic forest (Strausbaugh and Core 1977). Common species included red and white oak (Quercus rubra and Quercus alba), pignut and shagbark hickory (Carya glabra and Carya ovata), yellow-poplar (Liriodendron tulipifera), and American beech (Fagus grandifolia). Primary vegetation on grassland areas was tall fescue (Festuca arundinacea), sericea (Lespedesa cuneata), and autumn olive (Elaeagnus umbellata), but also included multiflora rose (Rosa multiflora), legumes such as birdsfoot Trefoil (Lotus corniculatus) and purple vetch (Vicia americana), and occasionally patches of planted wheat (Triticum aestiuum L.). There were two distinct shrub/pole treatments. The first type consisted mostly of black locust (Robinia pseudoacacia), European black alder (Alnus glutinosa), and Rubus species. The second type mostly consisted of coniferous species such as red pine (Pinus resinosa), scotch pine (Pinus sylvestris), and pitch pine (Pinus rigida).

\section{METHODS}

Red-shouldered Hawk presence or absence was quantified at 48 sampling points located in 14 stream drainages and spaced approximately 350-1,320 m apart (mean $=732.8)$. Sample 
points were divided equally among four treatment types with approximately equal numbers of sample points over the 3 mines. All 48 points were sampled monthly (February 2000-January 2001) over a 4-6 day period with at least 3 treatments sampled on a given day to minimize temporal variability between treatments. The order that points were sampled on a given day was randomly established during the first survey. Then the order in which points were sampled was systematically varied by the 3 mines and through 3 time periods: early, mid- and late-day.

Broadcasting conspecific vocalizations has been shown to be an effective way to survey targeted raptor species (Rosenfield et al. 1988, Mosher et al. 1990, Kennedy and Stahlecker 1993). During winter months, broadcast surveys were conducted from one-half hour after sunrise until 1600 hrs because raptors can be active throughout the day during cooler weather. During summer months, broadcast surveys were conducted from one-half hour after sunrise until $1300 \mathrm{hrs}$, because shifts in raptor activity in the afternoon may reduce the detectability of certain raptor species such as Red-tailed Hawks and Accipiters (Bunn et al. 1995). Two observers trained in identification of raptors by sight and sound were present at every survey. I was the primary observer and was present at each survey, while the second observer alternated between seven individuals. During the survey period, both observers simultaneously watched and listened for raptors. Surveys were not conducted in inclement weather (moderate to heavy rain, fog, or wind). Data recorded on surveys included weather conditions, nearest edge type, distance to edge, latency (time from start of survey until first raptor detection), raptor species detected, age and sex (if possible), behavior during detection (perch and call, flyby and call, silent perch, silent flyby, vocal only), time each individual bird was seen, estimated distance bird was from observer, and treatment in which a bird was first detected.

Based on the protocol suggested by Fuller and Mosher (1987), broadcast surveys lasted 10 minutes. Six calls were broadcast for a 20 second duration at 1 minute intervals ( 20 seconds 
of vocalization, followed by a 40 second listening period), leaving a final listening period of 4 minutes and 40 seconds and thus making a total of 10 minutes. A TOA Transistor ${ }^{\circledR}$ megaphone speaker with an attached CD player was used for broadcasting calls. The speaker was held $1.5 \mathrm{~m}$ above the ground and rotated $120^{\circ}$ between each broadcast. Broadcast call volume was adjusted between $100-110 \mathrm{db}$ at $1 \mathrm{~m}$ from the speaker.

Both Great-horned Owl (Bubo virginianus) and Red-shouldered Hawk vocalizations were used during the survey period. Both calls used were recorded from the Peterson Field Guide to Bird Songs of Eastern and Central North America CD (Peterson Field Guide Series 1990). The 6 vocalizations alternated between Great-horned Owl and Red-shouldered Hawk calls. Mosher and Fuller (1996) discovered that Great-horned Owl vocalizations were able to elicit responses from a number of raptor species on a single survey. McLeod and Andersen (1998) compared conspecific and Great-horned Owl calls in attracting Red-shouldered Hawks, and found that although Red-shouldered Hawks responded to Great-horned Owl vocalizations, response rates were higher for conspecific vocalizations earlier in the season and in the day. Therefore, both calls were used within a survey period to maximize detection of a number of raptor species as well as specifically target Red-shouldered Hawks. I randomly selected the Great-horned Owl or Red-shouldered Hawk call to start the first survey each day, and then alternated throughout the entire daily session.

For landscape-level habitat analysis, each survey point was geographically referenced using a global positioning system (GPS). Geographic Information Systems (GIS) were used to determine landcover from U.S. Geological Survey (USGS) Digital Orthophoto Quadrangle (DOQ) images within $564 \mathrm{~m}$ and $1000 \mathrm{~m}$ radius buffer zones placed around each point. The 564-m ( $\left.1 \mathrm{~km}^{2}, 100 \mathrm{ha}\right)$ radius zone was based on the minimum home range size for eastern Redshouldered Hawks (Crocoll 1994, Moorman and Chapman 1996, Howell and Chapman 1997). 
The $1000-\mathrm{m}\left(3.14 \mathrm{~km}^{2}, 314 \mathrm{ha}\right)$ radius zone was based on the maximum home range size and was more representative of a landscape scale (Bednarz and Dinsmore 1981, Crocoll 1994). Landcover within the two buffer zones was digitized into 9 classifications: early successional grassland habitat, mid-successional shrub/pole habitat (coniferous and deciduous), latesuccessional forest habitat (coniferous and deciduous), development, roads/bare ground, open water, and wetland (Fig. 3.1 and 3.2). The ESRI ${ }^{\circledR}$ ArcView extension Patch Analyst 2.2 was used to analyze both zones and calculate 19 landscape variables (Table 3.1).

Vegetation data collected at each point were used in microhabitat analysis. Four vegetation subplots of $11.3-\mathrm{m}$ radius $(0.04 \mathrm{ha})$ were sampled per point with one subplot centered on the point and 3 subplots approximately $35 \mathrm{~m}$ away from the center spaced $120^{\circ}$ apart. Tree species with tree diameter at breast height $(\mathrm{dbh}) \geq 7.5 \mathrm{~cm}$ were recorded within the 11.3 -m radius subplot. Shrubs, saplings, and poles taller than $0.5 \mathrm{~m}$ and with $\mathrm{dbh}<7.5 \mathrm{~cm}$, were counted within a 5-m radius centered on the subplot. Percent ground and canopy cover were estimated by using a "hit or miss" method with an ocular sighting tube at 20 points along four $11.3 \mathrm{~m}$ transects that radiated from the center of the vegetation subplot (James and Shugart 1970). Canopy height and slope were measured using a clinometer, aspect measured using a compass, and elevation derived from GPS. For grassland and shrub/pole points, stem density of vegetation, amount of cover, and grass height were measured using Wiens and Robel poles (Robel et al. 1970, Wiens and Rotenberry 1981). Organic litter depth was measured at four locations along the four transects (center, $1 \mathrm{~m}, 3 \mathrm{~m}$, and $5 \mathrm{~m}$ ) using a metric ruler on a compass. Vegetation data were summarized into 21 variables that were used in microhabitat analyses (Table 3.2).

Mean values of landscape and microhabitat characteristics were compared with $t$-tests for points with presence and absence of Red-shouldered Hawks. Stepwise logistic regression was 
used to identify landscape and microhabitat characteristics important to presence of Redshouldered Hawks. Stepwise multiple linear regression was used to identify characteristics that predicted Red-shouldered Hawk abundance. Abundance was log-transformed for multiple linear regression analyses. The entry and stay levels for all regression models were set at 0.3 and 0.1 , respectively. All statistical analyses were completed using the SAS ${ }^{\circledR}$ PROC LOGISTIC, PROC REG, and PROC TTEST procedures (SAS ${ }^{\circledR}$ Institute 1991).

For landscape analyses (1000 and 564 m zones), all points at which Red-shouldered Hawks were detected were used in logistic and multiple linear regression analyses. Models initially were developed using all 48 points in all 4 treatments to determine if broad-scale features enabled Red-shouldered Hawks to persist in a reclaimed mine landscape. Models then were developed for just the two forest treatments to more specifically examine features of fragmented forest and intact forest. For microhabitat analyses, points located in the grassland treatment were excluded from analyses, because no Red-shouldered Hawks were detected using this habitat. Additionally, detections were excluded from analyses when Red-shouldered Hawks were observed flying over but not within the microhabitat at the sample point or observed outside of the treatment at the sample point. Logistic and multiple linear regression models were also run twice for microhabitat analyses, once including points from the shrub/pole, fragmented forest, and intact forest treatments, and again including just points from the fragmented forest and intact forest treatments.

\section{RESULTS}

From February 2000-January 2001, 30 detections of Red-shouldered Hawks occurred on broadcast surveys, with 19 of the 48 points having at least one detection. At the landscape level, only one variable was retained in the final logistic regression models (Table 3.3); no variables 
were retained in the multiple linear regression models (Table 3.4). In the logistic regression model for the $1000 \mathrm{~m}$ zone when including only fragmented and intact forest points, the amount of wetland (WETLAND) in the landscape was retained as a predictor of presence of Redshouldered Hawks $\left(\mathrm{H} / \mathrm{L}\right.$ fit $\left.=0.498, \chi^{2}=3.580, P=0.059\right)$. A quasi-complete separation of the data points during the analysis questions the validity of the model fit (Fig. 3.3). However, wetlands occurred at 14 of the 19 points where Red-shouldered Hawks occurred and wetland habitat was more abundant $(t=-2.21, P=0.038)$ at forested points with Red-shouldered Hawks (Table 3.5).

Only 17 of the original 30 detections of Red-shouldered Hawks during broadcast surveys were used in microhabitat analyses, with 12 of the 36 points in shrub/pole, fragmented forest, and intact forest having at least one detection. Two of the 21 variables were retained in the final regression models for microhabitat analyses (Tables 3.3 and 3.4). When comparing points from the shrub/pole, fragmented forest, and intact forest treatments, only percent of ground area covered by woody debris (WOOD) $\left(R^{2}=0.197, F=8.320, P=0.007\right)$ was included in the final multiple linear regression model as a predictor of Red-shouldered Hawk abundance. Similarly, WOOD also was the only variable retained in the logistic regression model $\left(\mathrm{H} / \mathrm{L}\right.$ fit $=0.645, \chi^{2}=$ 5.633, $P=0.018)$. When just the points from the fragmented forest and intact forest were included in the microhabitat analysis, WOOD and distance to the nearest microhabitat edge (DISTEDGE) were retained in the final multiple linear regression model $\left(R^{2}=0.341, F=5.430\right.$, $P=0.013)$. Again, WOOD was included in the model for logistic regression $\left(\mathrm{H} / \mathrm{L}\right.$ fit $=0.937, \chi^{2}$ $=5.510, P=0.019)$. Woody debris cover was significantly greater $(t=-2.39, P=0.031)$ at points where Red-shouldered Hawks were detected (Table 3.6). 


\section{DISCUSSION}

The only significant predictor of Red-shouldered Hawk presence at the landscape level was the amount of wetland (WETLAND) within the $1000 \mathrm{~m}$ buffer zone for points within the two forest treatments. WETLAND was not significant for the overall logistic and multiple linear regression models that included all 48 points and all treatments. Many of the ponds and wetlands in the study area occurred within the early successional grassland found on the reclaimed mine sites. Throughout the year of surveys, only one juvenile Red-shouldered Hawk was recorded in the open grassland of the mine, so any significance WETLAND may have had on Red-shouldered Hawk presence for the overall landscape regression models was mitigated by the low occurrence of Red-shouldered Hawks in the grasslands. The significance of the variable WETLAND for points within fragmented and intact forest, where a majority of Red-shouldered Hawk observations occurred, suggests that Red-shouldered Hawks are frequenting landscapes that contain a higher amount of wetlands, but that also are associated with mature forest. Amount of open water (WATER) and distance to water/wetland (DISTWAT) were not significant in any of the landscape regression models, but means were slightly higher for WATER and slightly lower for DISTWAT for forest points with a Red-shouldered Hawk response, although not significantly (Table 3.5).

Wetlands have been associated with macrohabitat of Red-shouldered Hawks in a number of studies. Both Bednarz and Dinsmore (1981) and Bosakowski et al. (1992) found wetlands to be significant in the landscape surrounding Red-shouldered Hawks nests, while Howell and Chapman (1997) determined that a majority of Red-shouldered Hawk home ranges were within bottomland forest containing perennial streams, seasonal pools, and beaver ponds. Dykstra et al. (2001) found Red-shouldered Hawk response to broadcast surveys correlated with the number of small ponds within stream corridors. Red-shouldered Hawk association with wetlands may be 
related to diversity and abundance of amphibian prey. A majority of prey items delivered to Red-shouldered Hawk nests were prey associated with aquatic or moist habitats (Bednarz and Dinsmore 1981, Howell and Chapman 1997). Snakes, toads, lizards, and frogs are common prey for Red-shouldered Hawks in the eastern US (Peterson and Crocoll 1992, Crocoll 1994).

At the microhabitat level, percent of ground area covered by woody debris (WOOD) was the only variable consistently associated with Red-shouldered Hawk presence and abundance (Appendix Figure 3.1). The amount of coarse woody debris may be an important characteristic of Red-shouldered Hawk microhabitat because of the effect on abundance of prey species such as small mammals and herpetofauna. Small mammal abundance was greater within forested habitats having high levels of coarse woody debris (Loeb 1999, Menzel et al. 1999). On a strip mine in New Mexico, Ireland et al. (1994) found positive correlations between both species richness of small mammals and total herpetofaunal captures and the amount of rock and woody ground cover. Higher levels of prey species, especially amphibians and reptiles within the microhabitat may explain the higher occurrence of Red-shouldered Hawk observations in sites with a greater percentage of coarse woody debris.

For the two mature forest treatments, distance to nearest microhabitat edge (DISTEDGE) also was included as a significant predictor of Red-shouldered Hawk abundance (Appendix Figure 3.2), although the partial $\mathrm{R}^{2}$ for the variable was low indicating a weak relationship. Distance to microhabitat edge was not a predictior of presence. Red-shouldered Hawks generally were present at points only slightly farther from edges such as roads or openings (Table 3.6) than at points where they were absent. This suggests that Red-shouldered Hawks can tolerate a measure of fragmentation within the landscape, but have greater abundance in microhabitat that has fewer edges and openings. Generally, multiple detections of Redshouldered Hawks occurred at more intact forest points (Chapter 2). Both Moorman and 
Chapman (1996) and Crocoll and Parker (1989) found that Red-shouldered Hawks nest further away from edges and openings than Red-tailed Hawks and Broad-winged Hawks (Buteo playpterus), respectively. Also, habitat characteristics of Red-shouldered Hawks in a study comparing nests in southeastern Ohio and Maryland, showed that nests in Maryland (an area similar to West Virginia with respect to extensive forest and mountainous terrain) were further from forest openings than Ohio nests (Woodrey 1986).

This study, similar to many others, found that the amount of wetland within a landscape containing mature forest is an important habitat characteristic determining presence of Redshouldered Hawks. Although most variables associated with the reclaimed mine present on the study sites (ESGRASS, MSDECID, DISTHAB) were not significant at a landscape scale in regression analyses, there was significantly more ESGRASS and significantly less LSDEC and FOREST at forest sites in the $1000 \mathrm{~m}$ buffer zone where Red-shouldered Hawks were present when comparing means (Table 3.6). But, very few Red-shouldered Hawks were observed within reclaimed mine habitat, and then only during the non-breeding season. Many of the wetlands found along the drainages of forested valleys within the landscape, originated with fill ponds created to control soil erosion from reclaimed mine sites. Thus, it may be that Red-shouldered Hawks have taken advantage of the increased amount of wetlands created by past mining activities, by being present within the landscape, but in turn need an undetermined amount of mature forest present. The variable WOOD was overall the best indicator of greater Redshouldered Hawk abundance within the microhabitat at forested points. The amount of coarse woody debris within the microhabitat, in combination with more wetlands in the landscape, may provide for a large population of amphibians and reptiles, important in the diet of Redshouldered Hawks. Although the significance of DISTEDGE within the microhabitat may be less important than WOOD, higher abundance of Red-shouldered Hawks in forested points 
further from edges and openings, signifies that unbroken tracts of mature forest microhabitat have higher potential as hunting and breeding habitat for this species.

\section{ACKNOWLEDGEMENTS}

This research was conducted as part of an Environmental Impact Assessment on mountaintop removal mining involving terrestrial vertebrates. I would like to thank the West Virginia State legislature, which provided the funding for this project. I would also like to thank Arch Coal, Cannelton, and Amherst Corporation for allowing access to their properties. Ark Land Company provided field housing. The West Virginia Cooperative Fish and Wildlife Research Unit, USGS, BRD, at West Virginia University provided logistical support and field equipment. Special thanks go to the many people who helped with surveys, in particular Dorothy Tinkler and John D. Anderson, and to Mike Strager for providing help and guidance with GIS analysis. Thanks also to Petra Bohall Wood, John W. Edwards, and Roger J. Anderson for helpful comments on this manuscript.

\section{LITERATURE CITED}

BEDNARZ, J. C., and J. J. DINSMORE. 1981. Status, habitat use, and management of Redshouldered Hawks in Iowa. J. Wildl. Manage. 45: 236-241.

-----------, J. C., and J. J. DINSMORE. 1982. Nest-sites and habitat of Red-shouldered and Red-tailed Hawks in Iowa. Wilson Bull. 94: 31-45.

BELLEMAN, B. A. 1998. Red-shouldered Hawk breeding ecology and habitat use in central Minnesota. M. S. Thesis, University of Minnesota, St. Paul. 71 pp.

BENT, A. C. 1937. Life histories of North American birds of prey. Part I. U. S. Natl. Mus. Bull. 167. $409 \mathrm{pp}$.

BLOOM, P. H., M. D. MCCRARY, and M. J. GIBSON. 1993. Red-shouldered Hawks homerange and habitat use in southern California. J. Wildl. Manage. 57: 258-265. 
BOSAKOWSKI, T., D. G. SMITH, AND R. SPEISER. 1992. Status, nesting density, and macrohabitat selection of Red-shouldered Hawks in northern New Jersey. Wilson Bull. 104(3): 434-446.

BUCKELEW, A.R. and G.A. HALL. 1994. Red-shouldered Hawk Buteo lineatus. WV Breeding Bird Atlas, University of Pittsburgh Press, Pittsburgh, 215 pp.

BUNN, A. G., W. KLEIN, and K. L. BILDSTEIN. 1995. Time-of-day effects on the numbers and behavior of non-breeding raptors seen on roadside surveys in eastern Pennsylvania. $J$. Field Ornithol. 66(4): 544-552.

CROCOLL, S. T. 1994. Red-shouldered Hawk (Buteo lineatus). In The Birds of North America, No. 107 (A. Poole and F. Gill, Eds.). Philadelphia: The Academy of Natural Sciences; Washington D.C.: The American Ornithologists' Union.

, S. T., and J. W. PARKER. 1989. The breeding biology of Broad-winged and Redshouldered Hawks in western New York. J. Raptor Res. 23: 125-139.

DYKSTRA, C. R., F. B. DANIEL, J. L. HAYS, and M. M. SIMON. 2001. Correlation of Redshouldered Hawk abundance and macrohabitat characteristics in southern Ohio. The Condor 103: 652-656.

FORREN, J. D. 1981. Artificial perch use by raptors on reclaimed surface mines in West Virginia. M. S. Thesis, West Virginia University, Morgantown. 199 pp.

FULLER, M. R., and J. A. MOSHER. 1987. Raptor survey techniques. Pages 45-46 in B. A. Giron Pendleton, B. A. Millsap, K. W. Cline, and D. M. Bird, eds. Raptor management techniques manual. Natl. Wildl. Fed., Washington D. C.

HALL, G. A. 1983. West Virginia Birds: distribution and ecology. Spec. Publ. Carnegie Mus. Nat. Hist. No. 7, Pittsburgh. 180 pp.

HOWELL, D. L., and B. R. CHAPMAN. 1997. Home range and habitat use of Red-shouldered Hawks in Georgia. Wilson Bull. 109(1): 131-144.

IRELAND, T. T., G. L. WOLTERS, and S. D. SCHEMNITZ. 1994. Recolonization of wildlife on a coal strip-mine in northwestern New Mexico. Southwest. Nat. 39(1): 53-57.

JAMES, F. C. and H. H. SHUGART. 1970. A quantitative method of habitat description. Aud. Field Notes 24: 727-736.

KENNEDY, P. L. and D. W. STAHLECKER. 1993. Responsiveness of nesting Northern Goshawks to taped broadcasts of three conspecific calls. J. Wildl. Manage. 57(2): 249257.

LOEB. S. C. 1999. Responses of small mammals to coarse woody debris in a southeastern pine forest. J. of Mamm. 80(2): 460-471. 
MCLEOD, M. A. 1996. Red-shouldered Hawk habitat use and response to call-playback surveys in North-central Minnesota. M. S. Thesis, University of Minnesota, St. Paul. 77 pp.

M. A. and D. E. ANDERSON. 1998. Red-shouldered Hawk broadcast surveys:

Factors affecting detection of responses and population trends. J. Wildl. Manage. 62(4): 1385-1397.

MENZEL, M. A., W. M. FORD, J. LAERM, and D. KRISHON. 1999. Forest to wildlife opening: Habitat gradient analysis among small mammals in the southern Appalachians. For. Ecol. Mgmt. 114(2-3): 227-232.

MINDELL, D. P. 1978. Habitat use by Red-tailed Hawks in surface mined areas. M. S. Thesis, West Virginia University, Morgantown. 98 pp.

MOORMAN, C. E. and B. R. CHAPMAN. 1996. Nest-site selection of Red-shouldered and Red-tailed Hawks in a managed forest. Wilson Bull. 108(2): 357-368.

MORRIS, M. M. J., and R. E. LEMON. 1983. Characteristics of vegetation and topography near Red-shouldered Hawk nests in southwestern Quebec. J. Wildl. Manage. 47: 138-145.

MOSHER, J. A., M. R. FULLER, and M. KOPENY. 1990. Surveying woodland raptors by broadcast of conspecific vocalizations. J. Field Ornithol. 61(4): 453-461.

-----------, J. A. and M. R. FULLER. 1996. Surveying woodland hawks with broadcasts of Great- horned Owl vocalizations. Wildl. Soc. Bull. 24(3): 531-536.

PETERSON FIELD GUIDE SERIES. 1990. Peterson Field Guide to Bird Songs of Eastern and Central North America. Cornell Laboratory of Ornithology/Interactive Audio, Houghton Mifflin Co., Boston, Massachusetts.

PETERSON, J. M. C., and S. T. CROCOLL. 1992. Red-shouldered Hawk, Buteo lineatus. Pages 333-351 in K. J. Schneider and D. M. Pence, eds. Migratory nongame birds of management concern in the Northeast. U.S. Dep. Inter., Fish and Wildl. Serv., Newton Corner, Massachusetts. 400 pp.

PORTNOY, J. W., and W. E. DODGE. 1979. Red-shouldered Hawk nesting ecology and behavior. Wilson Bull. 91: 104-117.

ROBEL, R. J., J. N. BRIGGS, A. D. DAYTON, and L. C. HULBERT. 1970. Relationships between visual obstruction measurements and weight of grassland vegetation. J. of Range Mgmt 23: 295-297.

ROSENFIELD, R. N., J. BIELEFELDT, and R. K. ANDERSON. 1988. Effectiveness of broadcast calls for detecting breeding Cooper's Hawks. Wildl. Soc. Bull. 16(2): 210-212.

SAS INSTITUTE INC. 1991. SAS/STAT Guide for personal computers, version 6 edition. SAS Institute, Inc. Cary, North Carolina, 1028 pp. 
STRAUSBAUGH. P. D. and E. L. CORE. 1977. Flora of West Virginia. Seneca Books Inc., Morgantown, West Virginia, 1079 pp.

TITUS, K., and J. A. MOSHER. 1981. Nest-site habitat selected by woodland hawks in the central Appalachians. Auk 98: 270-281.

WIENS, J. A., and J. T. ROTENBERRY. 1981. Habitat associations and community structure of birds in shrubsteppe environments. Ecol. Monographs 51: 21-41.

WOODREY. M. S. 1986. Characteristics of Red-shouldered Hawk nests in southeast Ohio. Wilson Bull. 98(3): 469-471. 
Table 3.1. Abbreviations and descriptions of 19 variables used in landscape analyses of habitat use of Red-shouldered Hawks in southern West Virginia during February 2000-January 2001.

\begin{tabular}{|c|c|}
\hline Abbreviation & Description \\
\hline DEVELOP & Amount of human development (in ha). Includes residential and commercial buildings. \\
\hline ESGRASS & $\begin{array}{l}\text { Amount of early successional habitat (in ha). Consists of mostly grasslands and } \\
\text { scattered shrubs. }\end{array}$ \\
\hline LSCONIFER & $\begin{array}{l}\text { Amount of late successional habitat (in ha). Consists of mature, coniferous forest, } \\
\text { mostly Eastern Hemlock (Tsuga canadensis). }\end{array}$ \\
\hline LSDECID & $\begin{array}{l}\text { Amount of late successional habitat (in ha). Consists of mature, deciduous forest, } \\
\text { mostly Red Oak (Quercus rubra), White Oak (Quercus alba), Yellow Poplar } \\
\text { (Liriodendron tulipifera), and American Beech (Fagus grandifolia). }\end{array}$ \\
\hline MSCONIFER & $\begin{array}{l}\text { Amount of mid-successional habitat (in ha). Consists of coniferous shrub/pole, mostly } \\
\text { Red Pine (Pinus resinosa), Scotch Pine (Pinus sylvestris), and Pitch Pine } \\
\text { (Pinus rigida). }\end{array}$ \\
\hline MSDECID & $\begin{array}{l}\text { Amount of mid-successional habitat (in ha). Consists of deciduous shrub/pole, mostly } \\
\text { Black Locust (Robinia pseudoacacia), European Black Alder (Alnus glutinosa), } \\
\text { and Rubus species. }\end{array}$ \\
\hline ROAD & $\begin{array}{l}\text { Amount of primary/secondary roads, and bare ground (in ha). Includes all paved and most } \\
\text { gravel/dirt roads, and any area without vegetation. }\end{array}$ \\
\hline WATER & Amount of open water (in ha). Includes all streams, rivers, lakes, and ponds. \\
\hline WETLAND & Amount of emergent palustrine wetland (in ha). \\
\hline FOREST & Amount of total mature forest (in ha). LSCONIFER and LSDECID combined. \\
\hline \#FORPATCH & Number of total FOREST patches. \\
\hline MPSFOR & Mean patch size of FOREST. \\
\hline TCA & Total core area of FOREST in the landscape (100 m buffer used). \\
\hline MPSTCA & Mean patch size of total core area of FOREST in the landscape. \\
\hline ED & Edge density. Measure of amount of edge relative to the landscape area. \\
\hline SDI & Shannon's Diversity Index. Measure of relative patch diversity in the landscape. \\
\hline SEI & $\begin{array}{l}\text { Shannon's Evenness Index. Measure of patch distribution and abundance in the } \\
\text { landscape. }\end{array}$ \\
\hline DISTWAT & Distance to nearest WATER or WETLAND (in m). \\
\hline DISTHAB & Distance to next habitat/treatment type (in m). \\
\hline
\end{tabular}


Table 3.2. Abbreviations and descriptions of 21 variables used in microhabitat analyses of habitat use of Red-shouldered Hawks in southern West Virginia during February 2000-January 2001.

\begin{tabular}{ll}
\hline \multicolumn{1}{c}{ Abbreviation } & \multicolumn{1}{c}{ Description } \\
\hline ASPECT & Aspect (degrees) taken at the center of plot. \\
SLOPE & Slope (degrees) taken at the center of plot. \\
ELEV & Elevation (m) taken at center of plot. \\
DISTEDGE & $\begin{array}{l}\text { Distance to nearest microhabitat edge (m). Includes roads, } \\
\text { openings, and streams, or any other significant edge in forest } \\
\end{array}$ \\
microhabitat. \\
CANHT & Average canopy height (m). \\
SNAG & Amount of snags/dead trees.
\end{tabular}

Ground cover:

BAREGR

GREEN

WATER

LITTER

MOSS

WOOD

Percent of ground area covered by no vegetation.

Percent of ground area covered by vegetation.

Percent of ground area covered by water.

Percent of ground area covered by leaf litter.

Percent of ground area covered by moss.

Percent of ground area covered by woody debris.

Tree class categories:

SAPLING

POLE

Number of trees $<2.5 \mathrm{~cm}$ dbh.

MIDTREE

LGTREE

Number of trees $\geq 2.5-8 \mathrm{~cm} \mathrm{dbh}$.

Number of trees $>8-38 \mathrm{~cm}$ dbh.

Number of trees $>38 \mathrm{dbh}$.

Canopy cover:

CAN1

CAN3

Mean canopy cover for $<0.5-3 \mathrm{~m}$.

Mean canopy cover for $>3-6 \mathrm{~m}$.

CAN6

Mean canopy cover for $>6-12 \mathrm{~m}$.

UPCAN

Mean canopy cover for $>12 \mathrm{~m}$.

VERTSTR

Sum of all canopy cover categories. 
Table 3.3. Significant habitat variables from stepwise logistic regression for Red-shouldered Hawks at landscape (1000 m and $564 \mathrm{~m}$ buffer zones) and microhabitat scales in southern West Virginia during February 2000-January 2001.

\begin{tabular}{|c|c|c|c|c|}
\hline Variables & $\begin{array}{l}\text { Parameter } \\
\text { Estimate }\end{array}$ & $\begin{array}{l}\text { H/L Goodness- } \\
\text { of- fit }\end{array}$ & $x^{2}$ & $P$-value \\
\hline \multicolumn{5}{|l|}{$1000 \mathrm{~m}$ (all trmts) } \\
\hline & $-d$ & - & - & . \\
\hline \multicolumn{5}{|l|}{$1000 \mathrm{~m}(\mathrm{FR} / \mathrm{IN})^{\mathrm{b}}$} \\
\hline WETLAND & 1.565 & 0.498 & 3.580 & 0.059 \\
\hline \multicolumn{5}{|l|}{$564 \mathrm{~m}$ (all trmts) } \\
\hline & - & - & - & - \\
\hline \multicolumn{5}{|l|}{$\underline{564 \mathrm{~m}(\mathrm{FR} / \mathrm{IN})}$} \\
\hline & - & - & - & - \\
\hline \multicolumn{5}{|l|}{$\underline{\operatorname{Micro}(\mathrm{SH} / \mathrm{FR} / \mathrm{IN})^{\mathrm{c}}}$} \\
\hline WOOD & 1.538 & 0.645 & 5.633 & 0.018 \\
\hline \multicolumn{5}{|l|}{ Micro (FR/IN) } \\
\hline WOOD & 2.861 & 0.937 & 5.510 & 0.019 \\
\hline
\end{tabular}

${ }^{a}$ Includes all 4 treatments: grassland, shrub/pole, fragmented forest, and intact forest.

${ }^{\mathrm{b}}$ Includes fragmented forest (FR) and intact forest (IN) treatments only.

${ }^{\mathrm{c}}$ Includes shrub/pole (SH), fragmented forest (FR), and intact forest (IN) treatments only.

${ }^{\mathrm{d}}$ Indicates no significant variables for the model. 
Table 3.4. Significant habitat variables from stepwise multiple linear regression for Redshouldered Hawks at landscape (1000 m and $564 \mathrm{~m}$ buffer zones) and microhabitat scales in southern West Virginia during February 2000-January 2001.

\begin{tabular}{|c|c|c|c|c|c|c|c|}
\hline Variables & $\begin{array}{l}\text { Parameter } \\
\text { Estimate }\end{array}$ & $\begin{array}{c}\text { Partial } \\
\mathbf{R}^{2}\end{array}$ & $\begin{array}{c}\text { Model } \\
\mathbf{R}^{2}\end{array}$ & $\begin{array}{c}\text { Ind. } \\
\text { F-value }\end{array}$ & $\begin{array}{c}\text { Ind. } \\
\text { P-value }\end{array}$ & $\begin{array}{c}\text { Model } \\
\text { F-value }\end{array}$ & $\begin{array}{l}\text { Model } \\
\text { P-value }\end{array}$ \\
\hline \multicolumn{8}{|l|}{$1000 \mathrm{~m}$ (all trmts) ${ }^{\mathrm{a}}$} \\
\hline & $-{ }_{-1}^{d}$ & - & - & - & - & - & - \\
\hline \multicolumn{8}{|l|}{$1000 \mathrm{~m}(\mathrm{FR} / \mathrm{IN})^{\mathrm{b}}$} \\
\hline & - & - & - & - & - & - & - \\
\hline \multicolumn{8}{|l|}{$564 \mathrm{~m}$ (all trmts) } \\
\hline & - & - & - & - & - & - & - \\
\hline \multicolumn{8}{|l|}{$\underline{564 \mathrm{~m}(\mathrm{FR} / \mathrm{IN})}$} \\
\hline & - & - & - & - & - & - & - \\
\hline \multicolumn{8}{|l|}{ Micro (SH/FR/IN) } \\
\hline WOOD & 0.290 & 0.197 & 0.197 & 8.320 & 0.007 & 8.320 & 0.007 \\
\hline \multicolumn{8}{|l|}{$\operatorname{Micro}(F R / I N)$} \\
\hline WOOD & 0.474 & 0.248 & 0.341 & 7.250 & 0.013 & 5.430 & 0.013 \\
\hline DISTEDGE & 0.002 & 0.093 & & 2.960 & 0.100 & & \\
\hline
\end{tabular}

\footnotetext{
${ }^{\mathrm{a}}$ Includes all 4 treatments: grassland, shrub/pole, fragmented forest, and intact forest.

${ }^{\mathrm{b}}$ Includes fragmented forest (FR) and intact forest (IN) treatments only.

${ }^{c}$ Includes shrub/pole (SH), fragmented forest (FR), and intact forest (IN) treatments only.

${ }^{\mathrm{d}}$ Indicates no significant variables for the model.
} 
Table 3.5. Mean and standard error of the 19 landscape variables at both $1000 \mathrm{~m}$ and $564 \mathrm{~m}$ buffer zones for presence/absence of Red-shouldered Hawks at 48 broadcast survey points in southern West Virginia during February 2000-January 2001.

\begin{tabular}{|c|c|c|c|c|c|c|c|c|}
\hline \multirow[b]{3}{*}{ Variable } & \multicolumn{4}{|c|}{$1000 \mathrm{~m}$ buffer } & \multicolumn{4}{|c|}{$564 \mathrm{~m}$ buffer } \\
\hline & \multicolumn{2}{|c|}{ Presence } & \multicolumn{2}{|c|}{ Absence } & \multicolumn{2}{|c|}{ Presence } & \multicolumn{2}{|c|}{ Absence } \\
\hline & Mean & SE & Mean & SE & Mean & SE & Mean & SE \\
\hline \multicolumn{9}{|l|}{ All treatments: ${ }^{\mathrm{a}}$} \\
\hline DEVELOP & 0.82 & 0.40 & 1.94 & 0.67 & 0.04 & 0.03 & 0.62 & 0.38 \\
\hline ESGRASS & 93.50 & 19.41 & 102.36 & 15.83 & 28.11 & 6.50 & 37.11 & 5.80 \\
\hline LSCONIFER & 19.41 & 4.06 & 16.52 & 3.40 & 7.36 & 1.88 & 5.63 & 1.39 \\
\hline LSDECID & 152.70 & 17.92 & 160.53 & 17.38 & 47.25 & 6.61 & 45.44 & 6.23 \\
\hline MSCONIFER & 3.24 & 2.21 & 2.02 & 1.26 & 1.90 & 1.47 & 1.00 & 0.82 \\
\hline MSDECID & 31.44 & 10.24 & 16.64 & 5.38 & 11.79 & 4.33 & 5.75 & 2.14 \\
\hline ROAD & 9.10 & 1.51 & 10.47 & 2.10 & 2.33 & 0.62 & 3.29 & 0.68 \\
\hline WATER & 1.79 & 0.45 & 1.54 & 0.25 & 0.42 & 0.10 & 0.42 & 0.09 \\
\hline WETLAND & 0.58 & 0.15 & 0.54 & 0.12 & 0.24 & 0.08 & 0.18 & 0.05 \\
\hline FOREST & 172.11 & 19.58 & 177.05 & 17.75 & 54.61 & 7.07 & 51.07 & 6.52 \\
\hline \#FORPATCH & 5.84 & 0.89 & 5.69 & 0.84 & 2.79 & 0.32 & 3.55 & 0.56 \\
\hline MPSFOR & 61.95 & 20.65 & 80.87 & 20.34 & 25.48 & 6.40 & 28.64 & 6.38 \\
\hline TCA & 91.50 & 20.10 & 103.93 & 18.59 & 28.25 & 7.12 & 30.10 & 6.31 \\
\hline MPSTCA & 61.59 & 20.04 & 75.58 & 19.23 & 22.36 & 6.67 & 24.52 & 5.90 \\
\hline ED & 220.51 & 13.77 & 213.00 & 15.08 & 248.62 & 19.10 & 324.28 & 51.32 \\
\hline SDI & 2.99 & 0.11 & 2.82 & 0.13 & 2.37 & 0.12 & 2.30 & 0.12 \\
\hline SEI & 0.73 & 0.02 & 0.72 & 0.01 & 0.73 & 0.02 & 0.74 & 0.01 \\
\hline DISTWAT & 378.02 & 102.78 & 407.75 & 76.97 & 378.02 & 102.78 & 407.75 & 76.97 \\
\hline DISTHAB & 434.79 & 183.13 & 581.51 & 161.14 & 434.79 & 183.13 & 581.51 & 161.14 \\
\hline \multicolumn{9}{|l|}{ Forest treatments: ${ }^{\mathrm{b}}$} \\
\hline DEVELOP & 0.38 & 0.26 & 2.55 & 1.27 & 0.00 & 0.00 & 1.19 & 0.82 \\
\hline ESGRASS $^{\mathrm{c}}$ & 108.23 & 27.25 & 52.18 & 17.01 & 30.26 & 8.80 & 14.16 & 4.49 \\
\hline LSCONIFER & 23.65 & 5.40 & 17.86 & 4.64 & 10.80 & 2.64 & 7.44 & 2.25 \\
\hline LSDECID $^{\text {cd }}$ & 161.68 & 27.55 & 227.90 & 20.87 & 53.83 & 9.37 & 73.52 & 6.18 \\
\hline MSCONIFER $^{c}$ & 0.00 & 0.00 & 0.06 & 0.03 & 0.00 & 0.00 & 0.02 & 0.02 \\
\hline MSDECID & 7.42 & 4.30 & 4.74 & 2.67 & 2.35 & 1.55 & 0.95 & 0.68 \\
\hline ROAD & 8.68 & 2.27 & 5.99 & 1.99 & 1.38 & 0.51 & 1.78 & 0.75 \\
\hline WATER & 1.70 & 0.44 & 1.01 & 0.37 & 0.49 & 0.16 & 0.30 & 0.13 \\
\hline WETLAND $^{\text {cd }}$ & 0.82 & 0.23 & 0.28 & 0.12 & 0.34 & 0.13 & 0.07 & 0.03 \\
\hline FOREST $^{\mathrm{c}}$ & 185.34 & 29.42 & 245.76 & 19.71 & 64.63 & 9.19 & 80.96 & 5.56 \\
\hline \#FORPATCH & 5.73 & 1.17 & 5.77 & 1.55 & 2.82 & 0.46 & 4.00 & 1.05 \\
\hline MPSFOR & 83.73 & 34.47 & 140.06 & 39.09 & 34.12 & 10.18 & 49.21 & 11.16 \\
\hline TCA & 111.27 & 32.71 & 170.53 & 29.43 & 38.83 & 11.00 & 55.10 & 9.52 \\
\hline MPSTCA & 88.53 & 32.46 & 136.82 & 35.33 & 32.90 & 10.33 & 45.29 & 10.15 \\
\hline ED & 212.13 & 20.61 & 187.86 & 30.65 & 241.08 & 28.20 & 363.48 & 105.00 \\
\hline SDI & 2.93 & 0.16 & 2.51 & 0.24 & 2.34 & 0.19 & 2.08 & 0.23 \\
\hline SEI & 0.70 & 0.02 & 0.70 & 0.02 & 0.70 & 0.03 & 0.73 & 0.02 \\
\hline DISTWAT & 437.37 & 173.82 & 600.85 & 149.12 & 437.37 & 173.82 & 600.85 & 149.12 \\
\hline DISTHAB & 612.05 & 298.01 & 1034.15 & 318.51 & 612.05 & 298.01 & 1034.15 & 318.51 \\
\hline
\end{tabular}

${ }^{\mathrm{a}}$ Includes all 4 treatments: grassland, shrub/pole, fragmented forest, and intact forest, $\mathrm{n}=48$

${ }^{\mathrm{b}}$ Includes fragmented forest and intact forest treatments only, $\mathrm{n}=24$.

${ }^{\mathrm{c}}$ Indicates significant difference between means for the $1000 \mathrm{~m}$ buffer zone at $\alpha=0.1$.

${ }^{\mathrm{d}}$ Indicates significant difference between means for the $564 \mathrm{~m}$ buffer zone at $\alpha=0.1$. 
Table 3.6. Mean and standard error of the 21 microhabitat variables for presence/absence of Red-shouldered Hawks at broadcast survey points in southern West Virginia during Feburary 2000-January 2001.

\begin{tabular}{|c|c|c|c|c|c|c|c|c|}
\hline \multirow[b]{3}{*}{ Variable } & \multicolumn{4}{|c|}{ SH, FR, and IN treatments ${ }^{\mathrm{a}}$} & \multicolumn{4}{|c|}{ Forest treatments $^{\mathrm{b}}$} \\
\hline & \multicolumn{2}{|c|}{ Presence } & \multicolumn{2}{|c|}{ Absence } & \multicolumn{2}{|c|}{ Presence } & \multicolumn{2}{|c|}{ Absence } \\
\hline & Mean & SE & Mean & $\mathbf{S E}$ & Mean & SE & Mean & $\mathbf{S E}$ \\
\hline ASPECT & 0.98 & 0.18 & 1.02 & 0.12 & 1.19 & 0.17 & 1.06 & $\overline{0.14}$ \\
\hline SLOPE & 22.90 & 5.04 & 23.73 & 3.47 & 28.33 & 5.31 & 32.12 & 3.83 \\
\hline ELEV & 374.17 & 16.15 & 369.33 & 14.20 & 369.11 & 17.84 & 367.87 & 20.48 \\
\hline DISTEDGE & 63.97 & 24.94 & 58.54 & 15.58 & 65.81 & 33.58 & 49.90 & 18.35 \\
\hline CANHT & 17.73 & 2.28 & 14.89 & 1.89 & 21.68 & 1.14 & 21.29 & 1.20 \\
\hline SNAG & 52.63 & 17.37 & 30.74 & 6.61 & 70.17 & 19.98 & 42.10 & 8.06 \\
\hline
\end{tabular}

Ground cover:

$\begin{array}{rrrrrrrrr}\text { BAREGR } & 1.24 & 0.49 & 1.16 & 0.21 & 0.94 & 0.27 & 1.62 & 0.26 \\ \text { GREEN } & 8.54 & 1.44 & 11.40 & 1.30 & 6.08 & 0.64 & 6.87 & 0.67 \\ \text { WATER } & 0.13 & 0.09 & 0.18 & 0.06 & 0.17 & 0.12 & 0.28 & 0.09 \\ \text { LITTER } & 8.77 & 1.37 & 6.51 & 1.03 & 11.14 & 0.71 & 10.08 & 0.59 \\ \text { MOSS } & 0.32 & 0.13 & 0.25 & 0.05 & 0.28 & 0.11 & 0.35 & 0.07 \\ \text { WOOD }^{\text {cd }} & 1.04 & 0.23 & 0.44 & 0.10 & 1.39 & 0.20 & 0.70 & 0.11\end{array}$

Tree categories:

$\begin{array}{rrrrrrrrr}\text { SAPLING } & 7656.25 & 2389.40 & 4513.02 & 833.20 & 5684.03 & 1162.20 & 4656.25 & 700.99 \\ \text { POLE } & 684.90 & 133.39 & 884.11 & 150.22 & 743.06 & 139.54 & 822.92 & 125.51 \\ \text { MIDTREE } & 326.04 & 36.81 & 295.31 & 40.87 & 387.50 & 23.73 & 416.67 & 38.29 \\ \text { LGTREE } & 37.50 & 8.70 & 25.52 & 5.29 & 50.00 & 7.80 & 40.83 & 5.38\end{array}$

\section{Canopy cover:}

\begin{tabular}{rrrrrrrrr} 
CAN1 & 9.67 & 0.94 & 8.80 & 0.83 & 9.44 & 1.13 & 10.75 & 0.86 \\
CAN3 & 9.56 & 1.25 & 9.60 & 1.12 & 11.28 & 1.18 & 13.03 & 0.88 \\
CAN6 & 10.85 & 1.40 & 9.22 & 1.24 & 13.27 & 0.62 & 13.58 & 0.54 \\
UPCAN & 5.87 & 1.27 & 4.93 & 0.86 & 7.74 & 1.09 & 7.79 & 0.63 \\
VERTSTR & 47.68 & 5.74 & 42.40 & 5.17 & 57.22 & 3.84 & 60.75 & 2.11 \\
\hline
\end{tabular}

${ }^{a}$ Includes shrub/pole (SH), fragmented forest (FR), and intact forest (IN) treatments only, $\mathrm{n}=36$.

${ }^{\mathrm{b}}$ Includes fragmented forest and intact forest treatments only, $\mathrm{n}=24$.

${ }^{\mathrm{c}}$ Indicates significant difference between means for the SH, FR, and IN treatments at $\alpha=0.1$.

${ }^{\mathrm{d}}$ Indicates significant difference between means for the forest treatments at $\alpha=0.1$. 

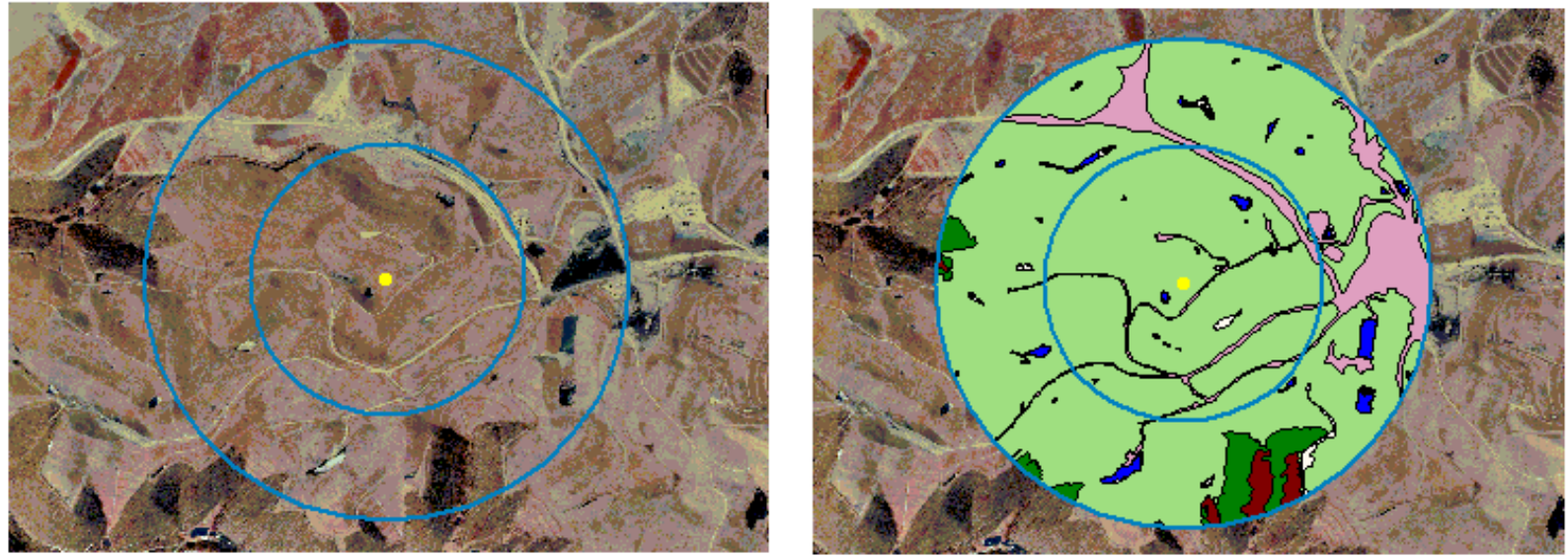

Example of grassland treatment point
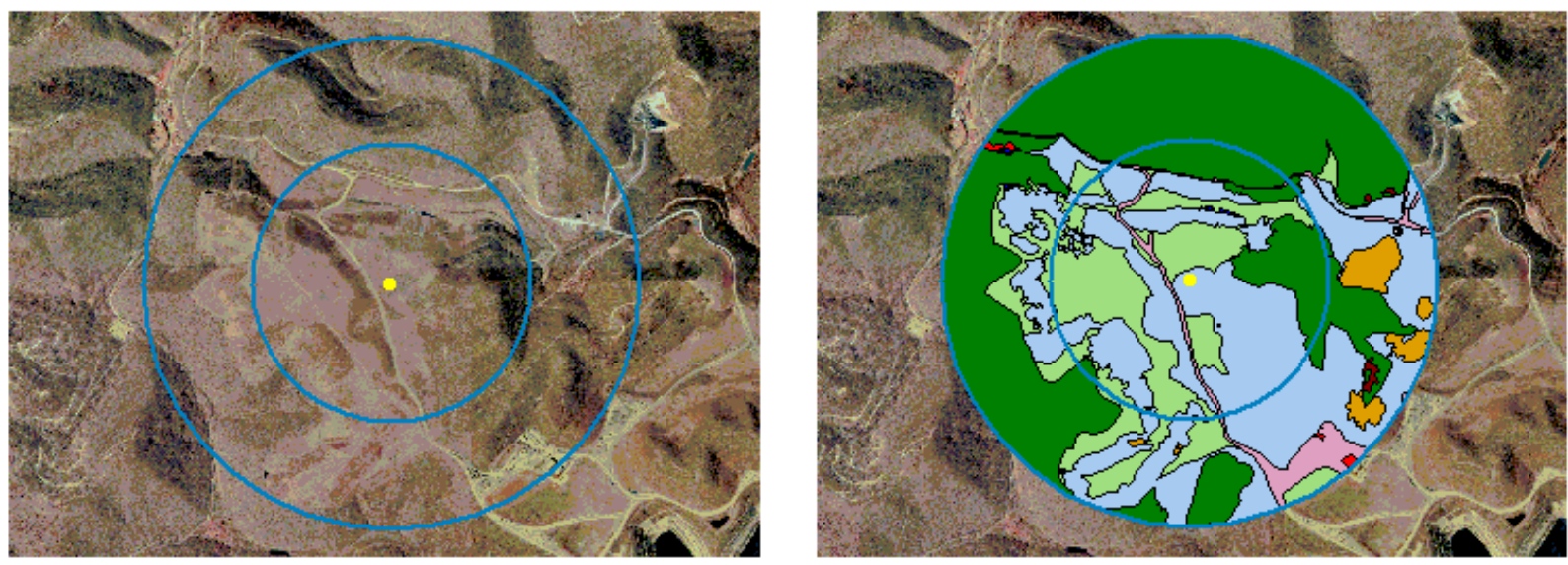

Example of shrub/pole treatment point

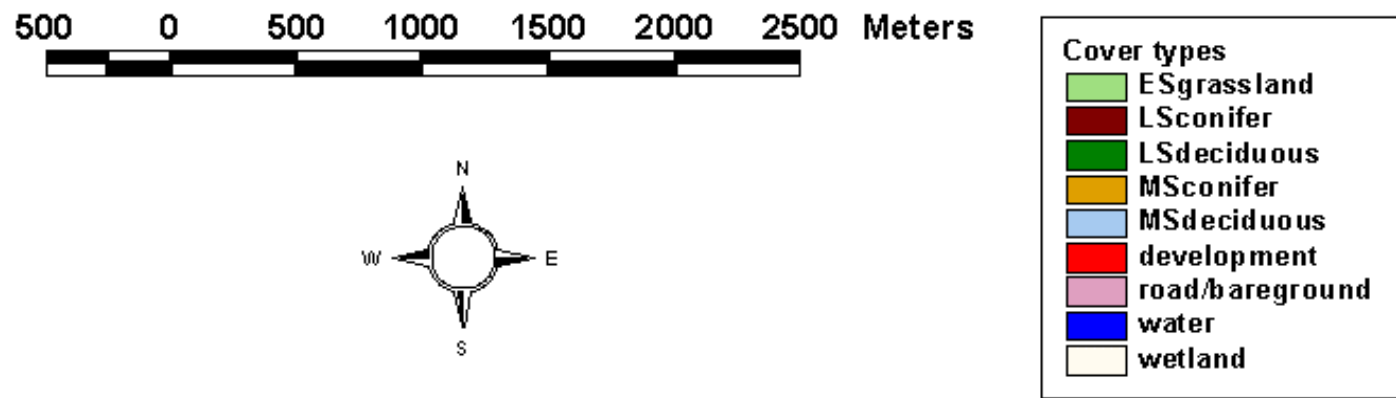

Figure 3.1. View of $1000 \mathrm{~m}$ and $564 \mathrm{~m}$ buffer zones with digitized landcover for points representing the grassland (top) and shrub/pole (bottom) treatments in southern West Virginia during February 2000-January 2001. 

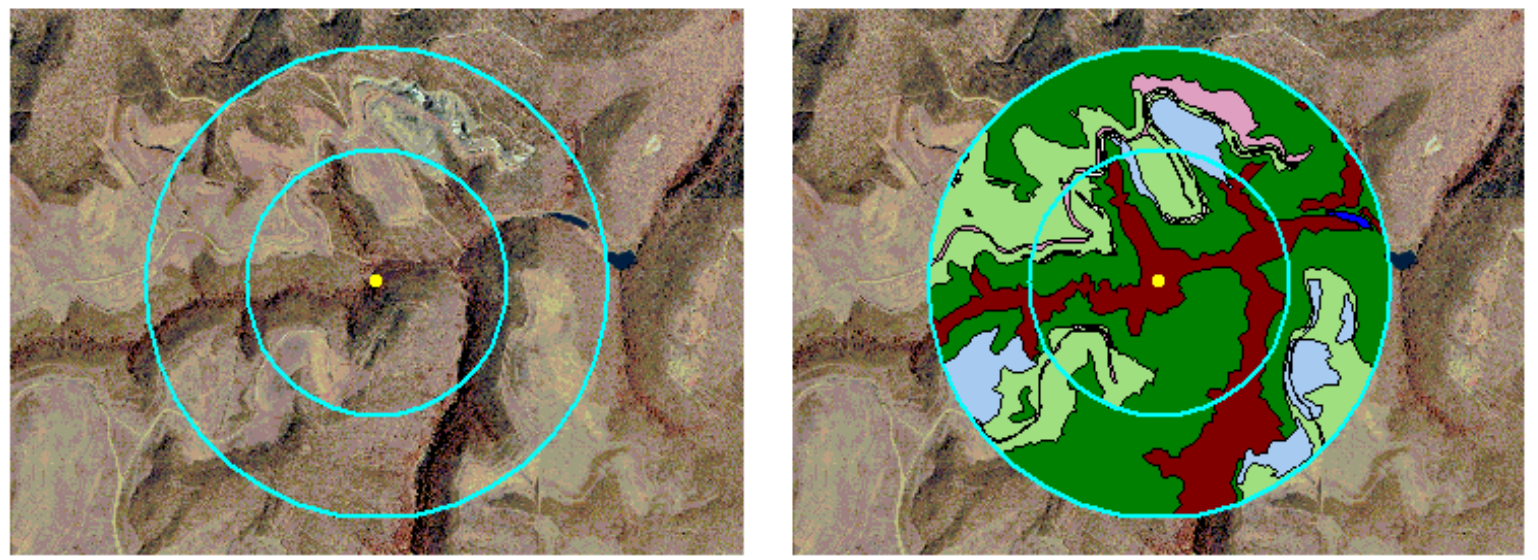

Example of fragmented forest treatment point
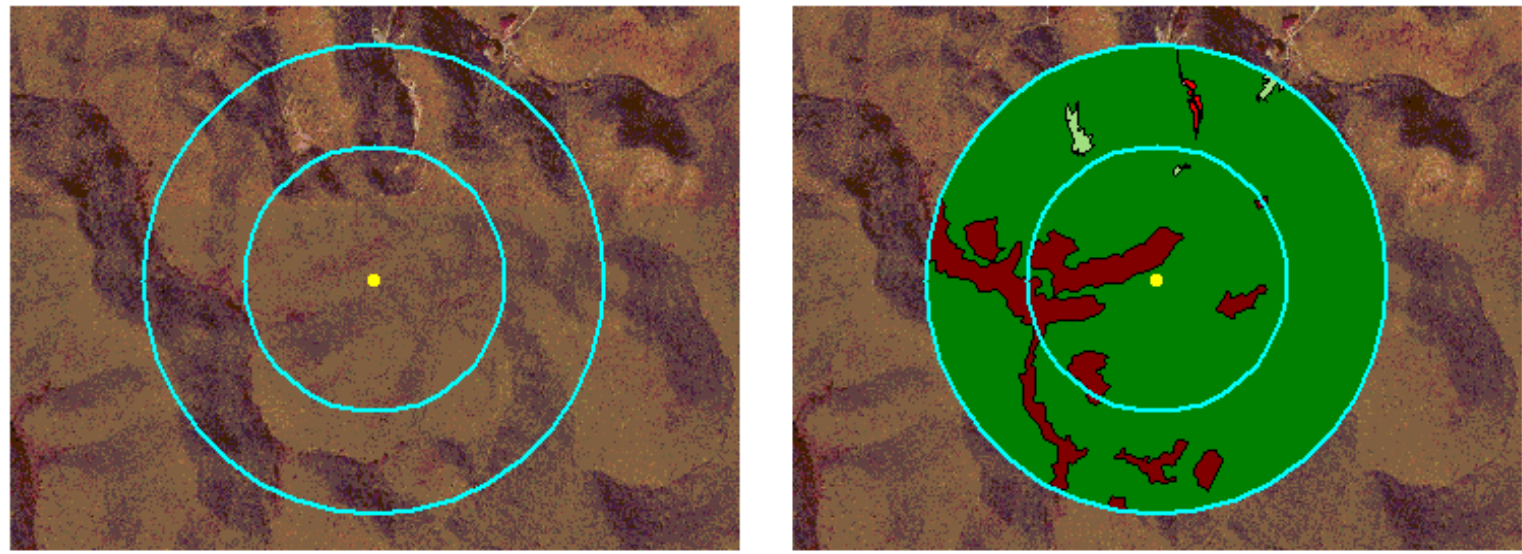

Example of intact forest treatment point
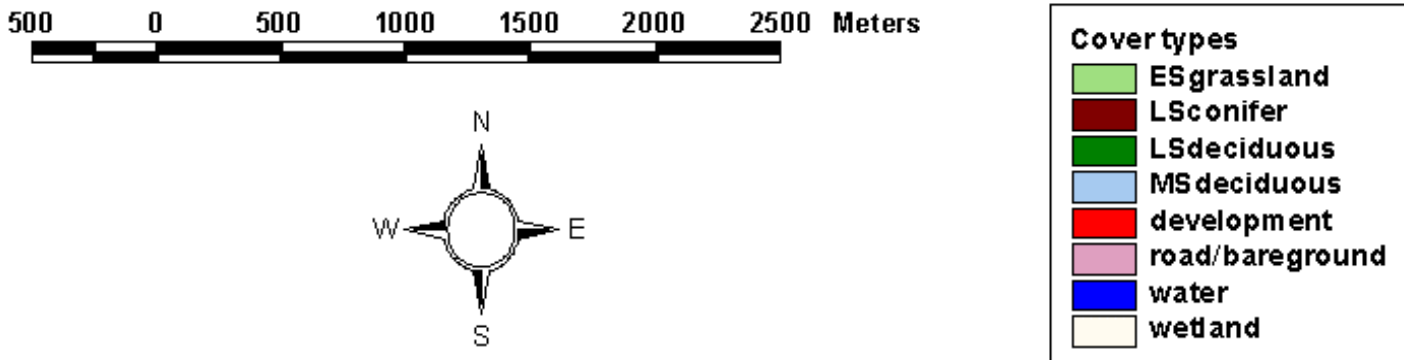

Figure 3.2. View of $1000 \mathrm{~m}$ and $564 \mathrm{~m}$ buffer zones with digitized landcover for points representing the fragmented forest (top) and intact forest (bottom) treatments in southern West Virginia during February 2000-January 2001. 


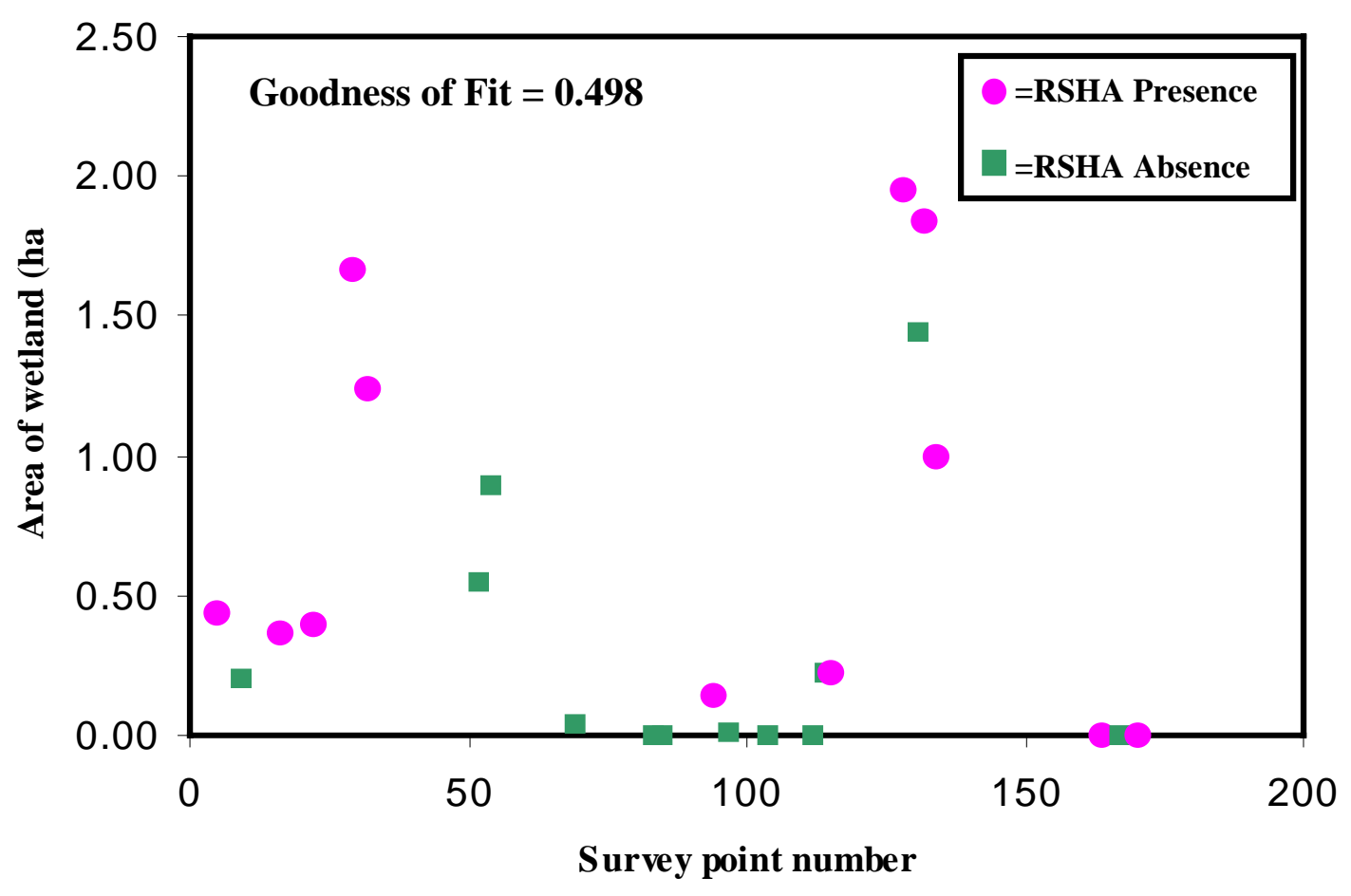

Figure 3.3. Logistic regression showing quasi-complete separation of data points for the relationship between presence and absence of Red-shouldered Hawks (RSHA) and the variable WETLAND in the fragmented and intact forest treatments. 


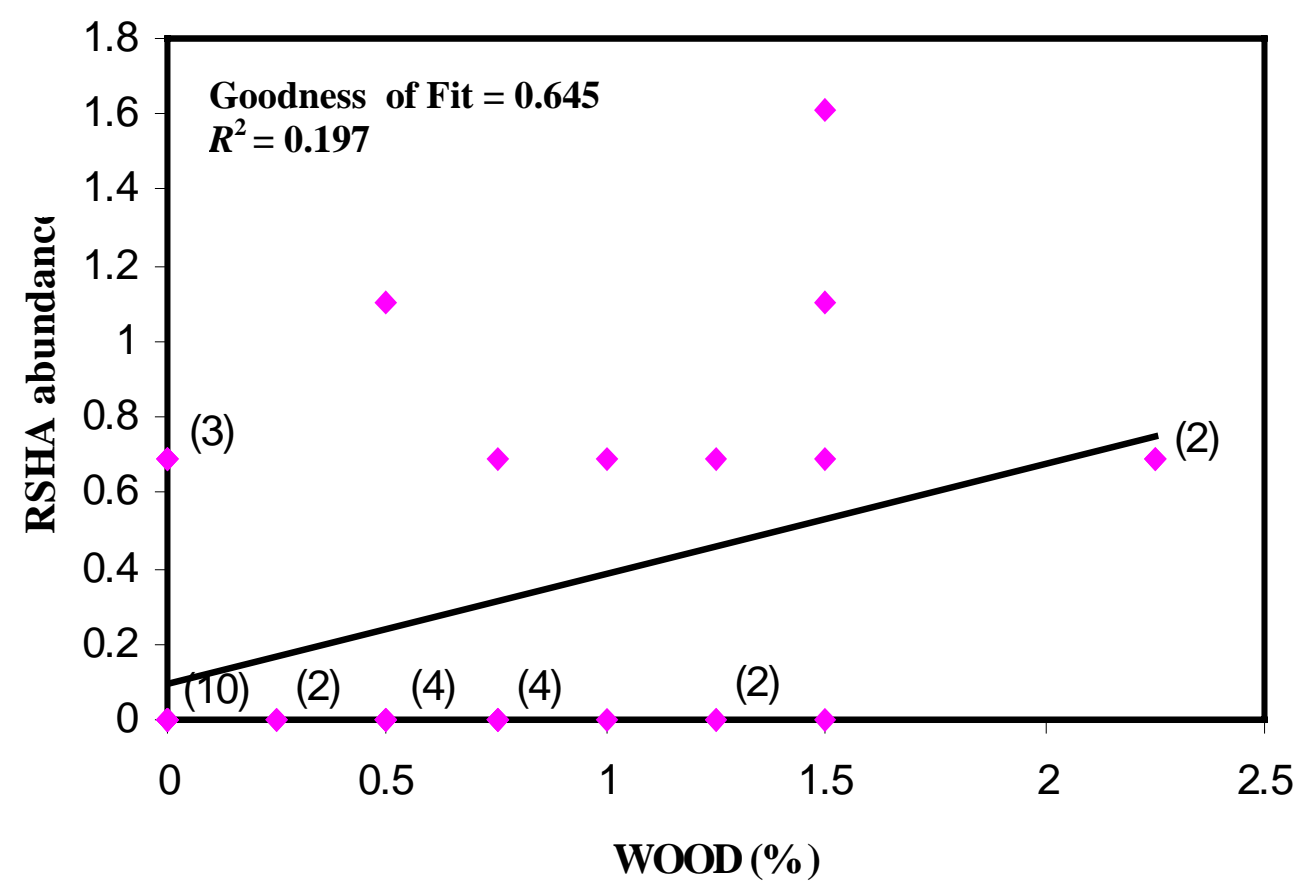

Appendix Figure 3.1. Relationship between abundance of Red-shouldered Hawks (LOG tranformed) and the variable WOOD (woody debris) with 36 points from the shrub/pole, fragmented forest, and intact forest treatments. Numbers in parenthesis show how many data points overlap. 


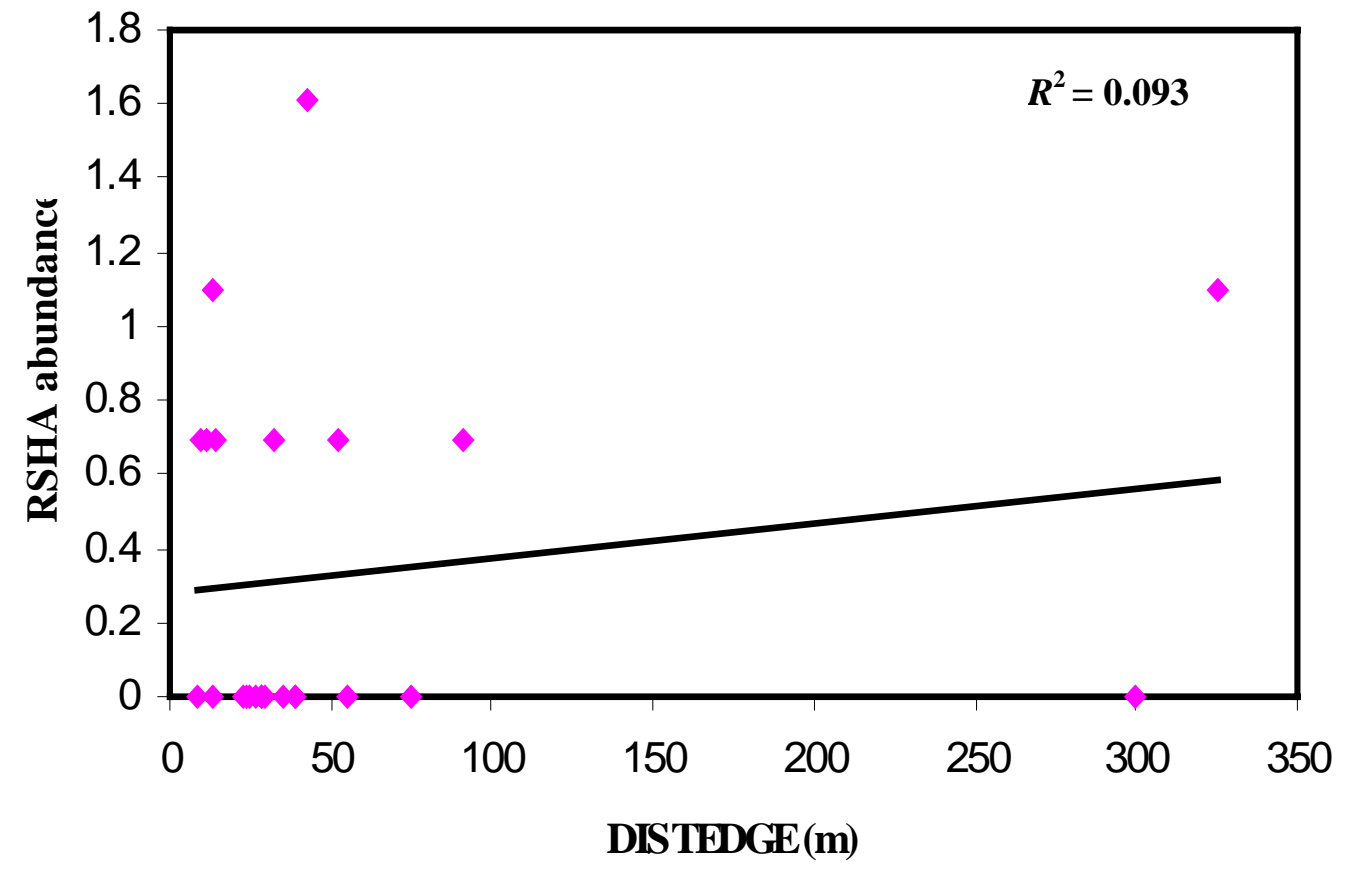

Appendix Figure 3.2. Relationship between abundance of Red-shouldered Hawks (LOG tranformed) and the variable DISTEDGE (distance to nearest microhabitat edge) for multiple linear regression model with points from the fragmented forest and intact forest treatments only. 


\section{VITA}

\section{Melissa J. Balcerzak}

Melissa Jean Balcerzak is the first daughter of Arthur and Jean Balcerzak and was born on Friday April 30, 1976 in Sewickley, Pennsylvania near Pittsburgh. She spent the early years of her childhood in St. Louis, MO, Perrysburg, OH, and Sharon, PA, and received her high school diploma from Kennedy Christian High School in Hermitage, PA in 1994. Later that fall, she attended the University of Maine in Orono studying wildlife in a 4-year program. Her junior year of study (1996-1997) was spent on national student exchange at the University of Alaska in Fairbanks, which was definitely one of the most memorable experiences of her life. It was in Alaska where she accepted her first ornithology-related internship mist-netting and banding songbirds at the Alaska Bird Observatory in Fairbanks.

Later, after graduating summa cum laude with a Bachelor of Science in Wildlife Ecology in May 1998 from the University of Maine, she accepted a field assistant position in the Monogahela National Forest in the mountains of West Virginia searching for songbird nests. It was her experience in West Virginia that later led her to apply for and be accepted into the graduate program at West Virginia University, while working for Tracy Aviary in Salt Lake City, Utah during the winter of 1998-99. In May 1999, she began her MS graduate research studying raptors at West Virginia University under Petra Bohall Wood. She is expected to graduate in December 2001 with her Master of Science in Wildlife and Fisheries Resources and is currently pursuing a professional career in the southwestern United States. 